\title{
The ocean-continent boundary off the western continental margin of Iberia: Crustal structure west of Galicia Bank
}

\author{
Robert B. Whitmarsh, ${ }_{5}^{1}$ Robert S. White, ${ }^{2}$ Susan J. Horsefield, ${ }^{23}$ Jean-Claude Sibuet, \\ Maurice Recq, Véronique Louvel ${ }^{4,6}$
}

\begin{abstract}
A seismic refraction transect across the Galicia Bank continental margin shows that the original continental crust thins westward from 17 to $2 \mathrm{~km}$ immediately east of a marginparallel peridotite ridge (PR). Immediately west of the PR, oceanic crust is only $2.5-3.5 \mathrm{~km}$ thick, but farther west (oceanward) it thickens to $7 \mathrm{~km}$. The PR caps a $\sim 60-\mathrm{km}$-wide lensshaped serpentinized peridotite body underlying both thinned continental and thin oceanic crust. When superimposed on a reflection time version of the velocity model, the $S$ reflector is clearly intracrustal at its east end. Westward, $S$ cuts down to lower crustal levels, eventually coinciding with the top of the serpentinized peridotite lens (original crust-mantle boundary). These observations render almost impossible the seafloor exposure of the PR by $S$ acting as a top-to-the-west detachment fault. Numcrical models of melting and borehole subsidence information constrain our rifting model. The easternmost continental crust experienced a total stretching factor of 4.3 (most likely in two stages); it probably occurred over $\sim 25$ m.y., with the highest rate of stretching at the beginning of the main earlier rift phase (Valanginian; 141$135 \mathrm{Ma}$ ). The 3 (4.7) $\mathrm{km}$ thick continental crust (depending on whether serpentinized peridotite is assigned to crust or mantle), which may include melt products, requires stretching factors of more than 11 (7) and a rift duration of more than 25 (13) m.y. The thin oceanic crust immediately west of the PR is explained by conductive cooling of the mantle during the long prebreakup stretching phase, which temporarily caused reduced melting immediately after breakup.
\end{abstract}

\section{Introduction}

Rifted continental margins form under the influence of magmatic and tectonic processes. To a great extent these processes are studied separately, since even their individual contributions to the formation of the observed broad spectrum of margin types, from so-called volcanic to nonvolcanic margins, have yet to be fully understood. A huge literature exists on the subject of extensional continental margins which has been reviewed recently by Ruppel [1995]; she stressed the importance of asthenospheric and lithospheric temperature, lithospheric rheology, and the duration and rate of extension. Aspects of melt production have been discussed, among others, by Bown and White [1995a,b], Eldholm and Grue [1994] and White [1992a]. A wide range of tectonic models of rifted margins has been proposed [e.g., Lister et al., 1991]. Some of the latest numerical geodynamic models of rifting are

\footnotetext{
'Challenger Division for Seafloor Processes, Southampton Oceanography Centre, Southampton, England.

${ }^{2}$ Bullard Laboratories, Department of Earth Sciences, University of Cambridge, Cambridge, England.

${ }^{3}$ Now at Esso Expro UK Ltd, Leatherhead, Surrey, England.

'IFREMER Centre de Brest, Plouzané, France.

'UFR Sciences et Techniques, Université de Bretagne Occidentale, Brest, France.

${ }^{6}$ Ecole et Observatoire de Physique du Globe, Institut de Physique du Globe de Strasbourg, Strasbourg, France.

Copyright 1996 by the American Geophysical Union.
}

Paper number 96JB02579.

0148-0227/96/96JB02579\$09.00 those presented by Bassi [1995], Boutilier and Keen [1994], Hopper and Buck [1993], and Sawyer and Harry [1991].

Observational techniques contribute in varying amounts to the study of magmatic and tectonic processes. Here we concentrate on the results of seismic refraction profiles that allow us to infer the amount of thinning of the continental crust, the thickness of crust formed during initial seafloor spreading, and, to a lesser degree, the intensity of magmatism that accompanied the lithospheric thinning.

On the Galicia Bank continental margin (adjacent to the northwest comer of the Iberian peninsula; see Figure 1, inset) tilted fault blocks, which are clearly expressed in the acoustic basement on multichannel seismic reflection profiles, provide evidence of synrift brittle deformation of the upper crust. For this reason the margin has been used as a key example to study mechanisms of thinning of continental crust during rifting and breakup [e.g., Boillot et al., 1989, 1995; Groupe Galice, 1979; Krawczyk and Reston, 1995; Louden et al,, 1991; Reston et al., 1996; Sibuet, 1992]. The conjugate to the Galicia Bank margin is the southeast Flemish Cap margin (east of Newfoundland). The two margins have different structural characters and hence are regarded as an asymmetric pair. Whereas the southeast Flemish Cap margin is narrow and presents a steep continental slope which probably corresponds to a major detachment fault [e.g., Parson et al., 1985; Sibuet, 1992] the Galicia Bank margin is wider and displays a system of margin-parallel tilted fault blocks that gently deepen westward with a mean spacing of about $15 \mathrm{~km}$ [Thommeret et al., 1988]. In addition, whereas on the Galicia Bank margin the maximum width of the ocean-continent transition (OCT; the OCT is defined [after Whitmarsh and Miles, 1995] as that part of the lithosphere, which may 
include crustal material, between the thinned continental crust characterized by tilted fault blocks, and the first oceanic crust formed by seafloor spreading) is about $30 \mathrm{~km}$ and the OCT is bounded to the west by a peridotite ridge, the width of the OCT on the southeast Flemish Cap margin is difficult to determine because estimates of the position of the seaward edge of the OCT differ by as much as $70 \mathrm{~km}$, depending on the authors [Tucholke et al., 1989; Todd and Reid, 1989].

A strong subhorizontal reflector, named $S$, which was discovered beneath the tilted fault blocks of the Galicia Bank margin [de Charpal et al., 1978], has been interpreted as an important detachment fault [e.g., Boillot et al., 1988a; Sibuet, 1992; Hoffman and Reston, 1992; Reston et al., 1996]. This detachment fault is observed over $50 \mathrm{~km}$ normal to the margin and only in the lower (western) part of the margin. It disappears close to the eastern edge of the peridotite ridge to the west and under the midcontinental slope to the east. According to different authors, either (1) the $S$ reflector represents the top of a serpentinized peridotite layer along its whole length and is therefore interpreted as the crust-mantle boundary at the time of formation of the margin [Boillot et al., 1987a] or (2) the $S$ reflector represents the upper part of the mantle peridotite layer over the westermmost $20 \mathrm{~km}$ and then cuts across the lower thinned continental crust and disappears at a level that was close to the brittle-plastic interface at the time of rifting [Sibuet et al., 1995].

Another characteristic feature of both the west Iberia and Newfoundland margins is the existence of a $7.5-7.65 \mathrm{~km} \mathrm{~s}^{-1}$ layer beneath the 2- to 4-km-thick crust of the OCT and the first formed oceanic crust [Whitmarsh et al., 1993; Reid, 1994]. The top of the layer exhibits a first-order velocity contrast, whereas the base appears to merge downward with the upper mantle. These authors suggested that the layer is serpentinized peridotite for reasons that are discussed later.

This paper presents the results of a series of wide-angle seismic refraction lines that form a transect across the Galicia Bank segment of the West Iberia continental margin. Our first objective was to determine the velocity structure of the margin and the depth of the $S$ reflector relative to the continental Moho. Establishing the location of $S$ with respect to the continental Moho provides an important test of models that explain the basement outcrop of the peridotite ridge by top-tothe-east or top-to-the-west motion along the $S$ detachment fault. The second objective was to determine the lateral extent of a possible serpentinized peridotite body, situated at the base of both the thimed continental crust and the adjacent oldest oceanic crust. Results obtained to meet the latter objective help to constrain the mechanisms of crustal deformation and to understand how the serpentinized peridotite body and associated peridotite ridge were emplaced. For example, if the body at the base of the crust is indeed serpentinized peridotite and not underplated material, then substantial synrift melting was absent and seawater must have penetrated the basement to depths of several kilometers. Our results also raise important questions about the origin of the associated, unusually thin, continental and oceanic crusts. Finally, the velocity structure of the margin and, in particular, the thinning of the continental crust are important in that they provide, together with other geological evidence, constraints on models of rifting and melting during continental extension. We show that the observed crustal thickness variation across the margin is consistent with numerical models of the melting that accompanies rifting and the onset of seafloor spreading.

\section{Data Acquisition}

We present seismic data collected over the Galicia Bank rifted continental margin off NW Iberia in April 1987 during the Reframarge cruise on board R/V Le Suroit. Four 80- to $150-\mathrm{km}$-long seismic refraction lines, as well as three shorter lines in the vicinity of a north-south peridotite ridge near the foot of the continental slope, were shot parallel and normal to the margin (Figure 1). The principal east-west line followed the deep multichannel seismic (MCS) profile GP101 [Mauffret and Montadert, 1987]. The observations along the seismic refraction lines have been modelcd using computed travel times and synthetic seismograms. The preferred velocity model was confimed by gravity modeling, based on data acquired during the ZEEGASC cruise of the Institut Français de Recherche pour l'Exploitation de la Mer (IFREMER) in 1992, to arrive at a model of the deep structure of the margin from the continental crust of Galicia Bank to the oceanic crust of the Iberia Abyssal Plain.

The seismic source was an array of eight 16.4-1 (1000 cubic inches) Bolt air guns, deployed in two lines of four and towed at about 5 knots $\left(2.5 \mathrm{~m} \mathrm{~s}^{-1}\right)$ at a depth of $20 \mathrm{~m}$ below the surface. Shots were fired every $120 \mathrm{~s}$, about $300 \mathrm{~m}$ apart. Up to three digital ocean bottom seismographs (DOBS) [Kirk et al., 1982] were deployed along each line. They recorded signals from three orthogonal geophones and one hydrophone at 75 samples $s^{-1}$. Seismic reflection profiles were also acquired along each profile concurrently with the wide-angle recordings, and sometimes separately using two 1.3-1 (80 cubic inches) water guns, to image the shallow structure down to the top of acoustic basement. These profiles were summed over four channels, filtered, and displayed on electrostatic paper. The higher-quality MCS line GP101 was used to constrain the basement shape along the refraction line normal to the margin. Navigation was by a combination of Loran-C and Global Positioning System (GPS) satellite fixes.

Shot-to-receiver ranges were determined by the semigraphical technique described by Whitmarsh et al. [1986]. Ranges were adjusted until the computed water wave hodochron matched the observed travel time of the direct water wave or of the bottom surface reflection. The hodochron was computed by ray tracing through a sound speed model of the sea based on expendable bathythermographs acquired during the cruise and on deeper historical conductivitytemperature-depth data from the same area. Where a water wave did not arrive within the recording window (at offsets greater than $70 \mathrm{~km}$ ), the ranges were found using the shot spacings determined from the DOBS that was next in line, but closer, to the shots.

\section{Modeling the Observations}

The DOBS record-sections were travel time and amplitude modeled in Brest, Cambridge, and Wormley using a program based on Maslov asymptotic ray theory developed by Chapman and Drummond [1982]. Initial models were set up using (1) reflection profiles, sonobuoy results [Sibuet et al., 1987], and Ocean Drilling Program (ODP) results [Boillot et al., 1987b, 1988c] for the structure above acoustic basement and (2) one-dimensional models derived from slope-intercept travel time computations for an estimate of the deeper structure. The margin-parallel lines and the short reversed line across the peridotite ridge were modeled first to provide 


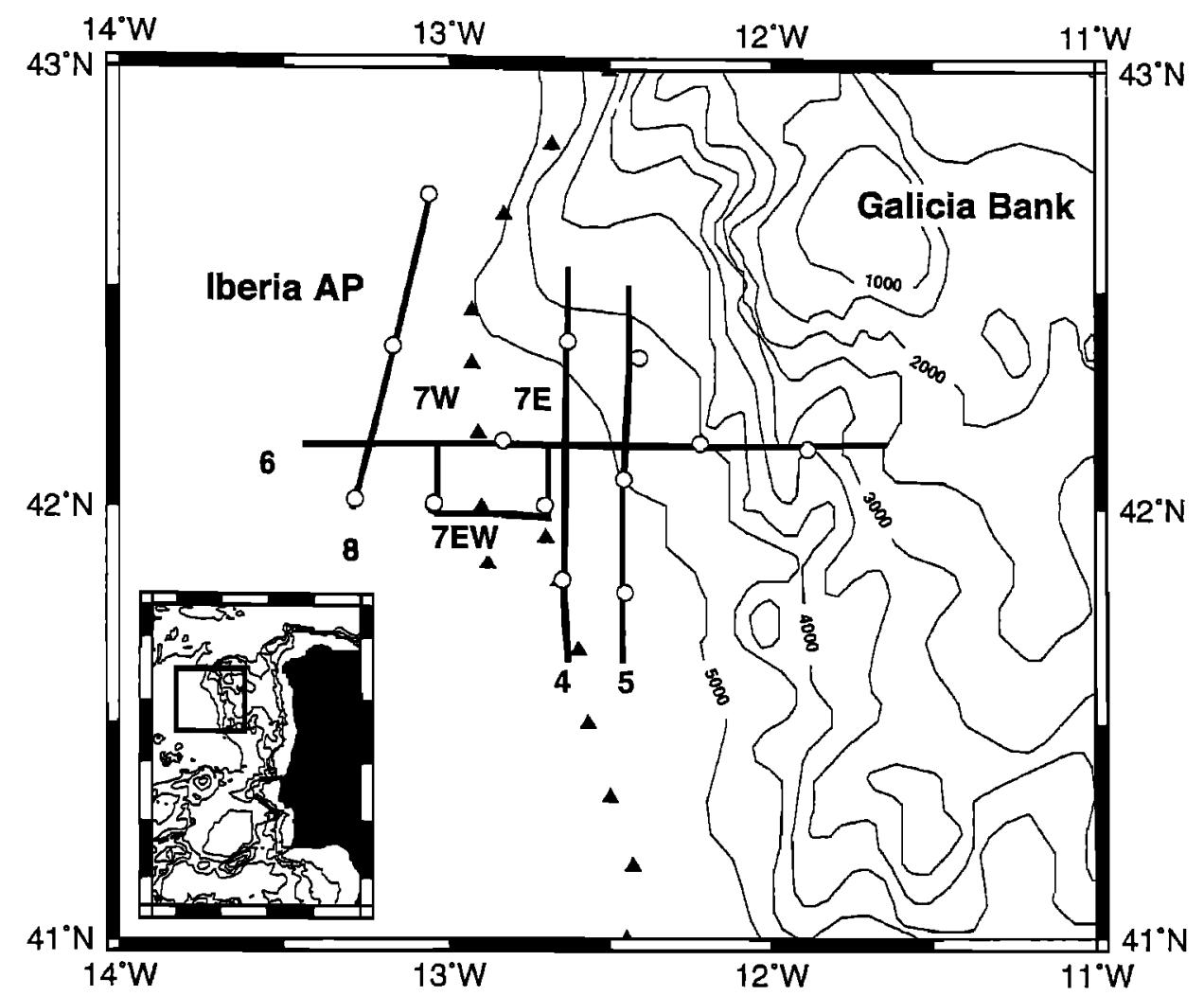

Figure 1. Bathymetric chart (depths in meters) around the western margin of Galicia Bank showing (bold lines) the location of the Réframarge seismic refraction lines 4, 5, 6, 7EW, 7E, 7W, and 8 (open circles are DOBS locations). Triangles mark the probable position of the peridotite ridge which lies at the landward edge of oceanic crust [Beslier et al., 1993]. Location relative to western Iberia is shown by the box in the inset.

control points at their intersections with the margin-normal line and an estimate of the likely structure of the upper part of the peridotite ridge, respectively.

The modeling strategy follows that outlined by Peirce and Barton [1991], except that we do not model sedimentary arrivals $\left(P_{s}\right)$. Apart from the fact that most $P_{s}$ phases are not visible on the record sections, the determination of precise sediment velocities is not as important in modeling the deep crustal structure as is ensuring that the travel times of ray paths within the sediments are accurate. The revised strategy is thus as follows:

1. First, the travel times and amplitudes of near-offset upper crustal arrivals $\left(P_{g}\right)$ are modeled close to each instrument, and the upper crustal velocity structure is interpolated between DOBSs.

2. Second, the travel times of lower crustal $\left(P_{g}\right)$ and upper mantle $\left(P_{n}\right)$ phases and, where appropriate, mantle reflections $\left(P_{m} P\right)$ are modeled by altering the velocity structure and geometry down to the Moho until a satisfactory fit is obtained.

3. Finally, after obtaining an acceptable travel time fit for arrivals at all the instruments, the velocity gradients within layers and the velocity contrasts at interfaces are adjusted (keeping the average velocities, and hence the travel times, unchanged), until an acceptable fit is obtained between the synthetic seismograms and the main amplitude features of the data. We concentrate on modeling the first arriving energy and, where appropriate, the mantle reflections and the amplitudes in the vicinity of the Moho triplication. In some cases the amplitude fluctuations of first arrivals are dominated by the focusing/defocusing effects of basement relief. In a few places, discontinuous late-arriving energy is visible. This energy may be caused by locally stronger intracrustal multiples or by out-of-plane reflections; in the former cases we have not attempted to reproduce such minor features in the synthetics in view of the poor constraints on intracrustal velocity contrasts.

The modeling results are discussed below, together with the main features of the record sections. For each instrument the observed data are shown together with the synthetic seismograms (with superimposed picked travel times) and the ray-traced model (Figures 2-6). For clarity of presentation, the ray-traced models are displayed with a much reduced number of rays.

The quality of the data is good, with high trace-to-trace coherence, and first, and some second, arrivals can be recognized out to about $80 \mathrm{~km}$. At the largest ranges, picks were sometimes made on traces for which the signal-to-noise ratio had been improved by summing three adjacent traces. The source waveform has a predominant frequency of $8 \mathrm{~Hz}$ and is relatively long ( $-0.5 \mathrm{~s})$ as a result of using only one size of air gun chamber in the source array. This means that there is a significant amount of interference between phases arriving at similar times, but on the other hand, this waveform is relatively easy to recognize, even in the presence of noise, and the amplitudes are higher than would have been the case if smaller air guns had been substituted for some of the 16.4-1 

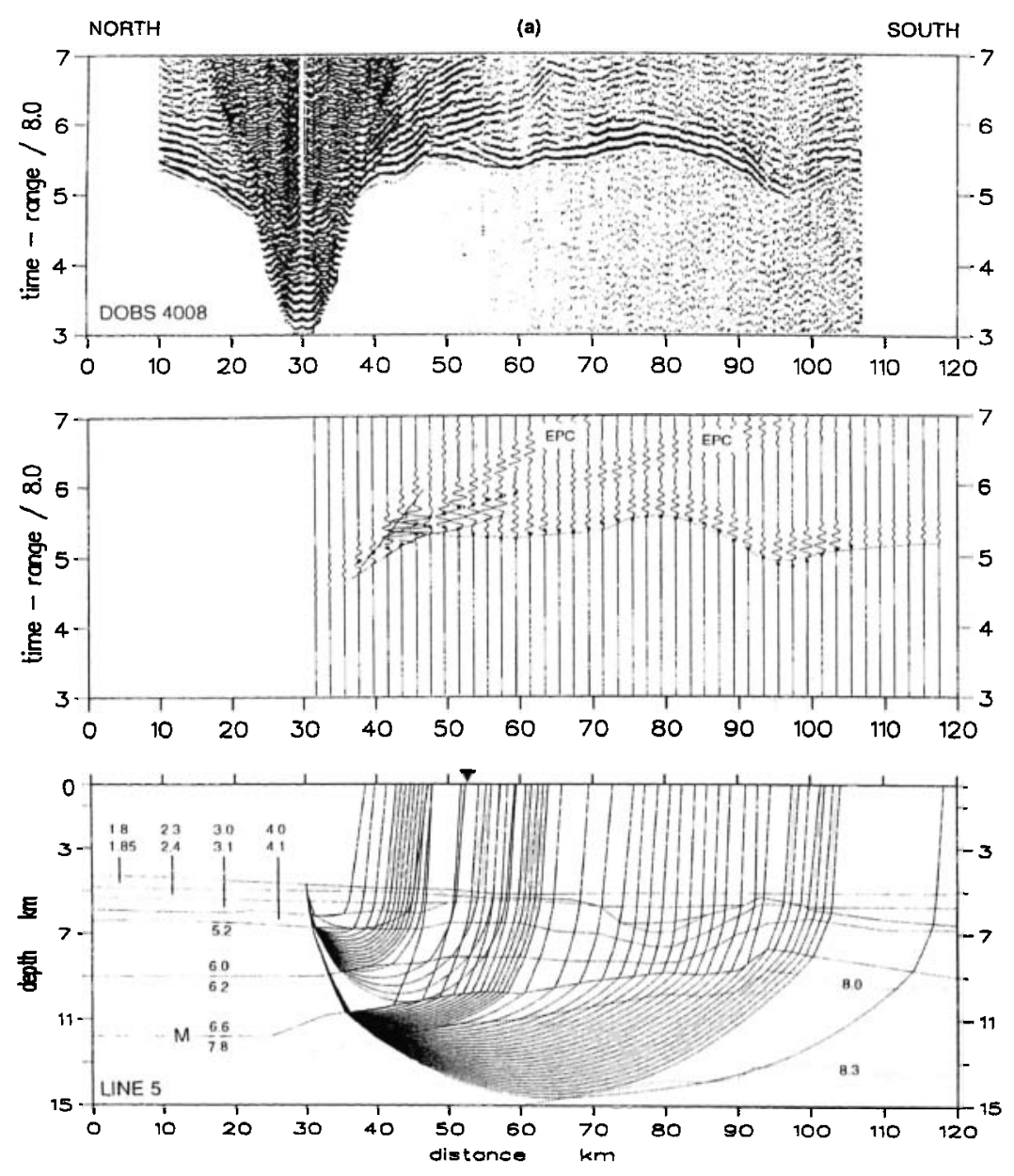

Figure 2. (top) Vertical-geophone record sections, (middle) synthetic seismograms, and (bottom) ray diagrams for line 5. The observed data have been low-pass filtered below $25 \mathrm{~Hz}$ (above this frequency the air gun source produced little energy) and are displayed as variable area plots at a common amplification scale (except where stated). Times are reduced to $8 \mathrm{~km} \mathrm{~s}^{-1}$, and amplitudes are scaled by distance. On the synthetic seismograms, dots indicate travel times picked from the record section, and lines are computed hodochrons. EPC indicates end point corrections which are artifacts of the computational method. In the model, velocities are indicated in kilometers per second, dotted lines are isovelocity lines (where appropriate) at $0.2 \mathrm{~km} \mathrm{~s}^{-1}$ intervals from 5.0 to $8.0 \mathrm{~km} \mathrm{~s}^{-1}$ inclusive, dashed lines indicate specific velocity horizons and $\mathrm{M}$ indicates the Moho. For clarity many rays have been omitted from the ray diagrams. The intersection with line 6 is shown by a solid arrow. (a) DOBS 4008 , (b) DOBS 1017 . The poor fit of the crustal second arrivals is suspected to be a function of late picking of the onset of a ringy signal and of the ambiguous character of the reflection profile along line 5, (c) DOBS 2019.

guns in order to tune the array. With few exceptions, the models presented here reproduce the travel times to well within $100 \mathrm{~ms}$ of those observed; in the worst case the misfit is $200 \mathrm{~ms}$.

The models for each north-south line are presented below in sequence from east to west; finally we present models for the two lines shot in an east-west direction. The locations of the lines, including DOBS sites, are shown in Figure 1.

\section{Line 5}

This easternmost, 95-km-long line was shot over a seafloor which shoals steadily northward. Three sedimentary layers, distinguished on the reflection profile, overlie an acoustic basement with up to $1.6 \mathrm{~s}$ relief beneath the southern third of the line. The model is constrained by observations at three DOBSs along the line.
DOBS 4008 (Figure 2a). Other than the relatively strong sedimentary arrivals, the observed amplitudes vary only slightly with range (except for the weak arrivals beyond 95 $\mathrm{km}$ model range). This behavior is reproduced by the synthetic seismograms.

DOBS 1017 (Figure 2b). This record section is unusual in that middle and lower crustal second arrivals are seen out to ranges of 20-36 km from the DOBS. Since the crust is thin beneath this line, $P_{n}$ arrivals appear as first arrivals beyond about $15 \mathrm{~km}$ range on both sides of the DOBS. Other than the relatively strong sedimentary arrivals, the observed amplitudes vary only slightly with range (except for the weak defocused arrivals around $37 \mathrm{~km}$ south of the DOBS), as do the synthetic seismograms.

DOBS 2019 (Figure 2c). To the north of the DOBS the first arrivals are the $P_{n}$ phase at all ranges beyond $7 \mathrm{~km}$. The 



Figure 2. (continued)

slight reduction in amplitude between $27-37 \mathrm{~km}$ north of the DOBS is well matched by the synthetics.

\section{Line 4}

This 103-km-long line was recorded by two DOBSs; it was shot parallel to the margin about $15 \mathrm{~km}$ west of line 5 and a few kilometers west of the westernmost fault block seen on the intersecting reflection profile GP101. The seabed shoals gently northward over the northem half of the line. On the reflection profile three sedimentary layers, overlying an acoustic basement with up to $1.5 \mathrm{~s}$ relief, were distinguished.

DOBS 2018 (Figure 3a). The signal-to-noise ratio around the first arrivals is rather low beyond $51 \mathrm{~km}$ model range, and it is only beyond this distance that the fit of the computed travel times is sometimes as poor as $\mathbf{2 0 0} \mathrm{ms}$. We attribute the poor fit to picking onsets late in the presence of noise (see below). There is direct evidence of a velocity of $\sim 7.2 \mathrm{~km} \mathrm{~s}^{-1}$ at the base of the crust from rays that tum in that region and produce first arrivals over the model range $53-63 \mathrm{~km}$.

DOBS 4007 (Figure 3b). The computed travel times fit the first arrivals to well within $100 \mathrm{~ms}$ at this DOBS; this supports the idea that some DOBS 2018 arrivals were picked late. The relatively strong crustal arrivals are adequately modeled by the synthetic seismograms. Although the strong arrivals between 33 and $44 \mathrm{~km}$ model range are not reproduced in the synthetics, the slight increase in amplitude north of $48 \mathrm{~km}$ model range is matched by the computed seismograms.

\section{Line 7E}

This 29-km-long N-S line was one of an orthogonal set of lines (here called lines 7E, 7W, and 7EW) shot over and on either side of the peridotite ridge, which outcrops on the seafloor some $15 \mathrm{~km}$ south of line 6 (Figure 1). Results from this line were presented by Whitmarsh et al. [1993] as their line 7. Since the line was recorded by a single DOBS, the lack of reversed paths leaves some doubt about the correcmess of the model even though the line was shot parallel to the margin; this doubt is reinforced by the difficulty of matching the line 7E structure at the intersection with line 6 (Figure 7). The difference lies principally in the rather high velocity of $2.58 \mathrm{~km} \mathrm{~s}^{-1}$ assigned to the whole sedimentary layer for line $7 \mathrm{E}$ and the knock-on consequences for the deeper structure. The structures are otherwise very similar. Line 7E was therefore not used to constrain the modeling of Line 6 . However, since line 7E was shot along the margin, i.e., normal to the direction of crustal thinning, it may provide important direct evidence from first arrivals for velocities of about $7.4 \mathrm{~km} \mathrm{~s}^{-1}$ at the base of the crust.

\section{Line $7 \mathrm{~W}$}

This 28-km-long north-south line was shot west of the peridotite ridge to a single DOBS, and the ray-tracing model was constrained by a coincident seismic reflection profile. Results from this line were presented by Whitmarsh et al. [1993] as their line 6. Although the line is unreversed, it can 

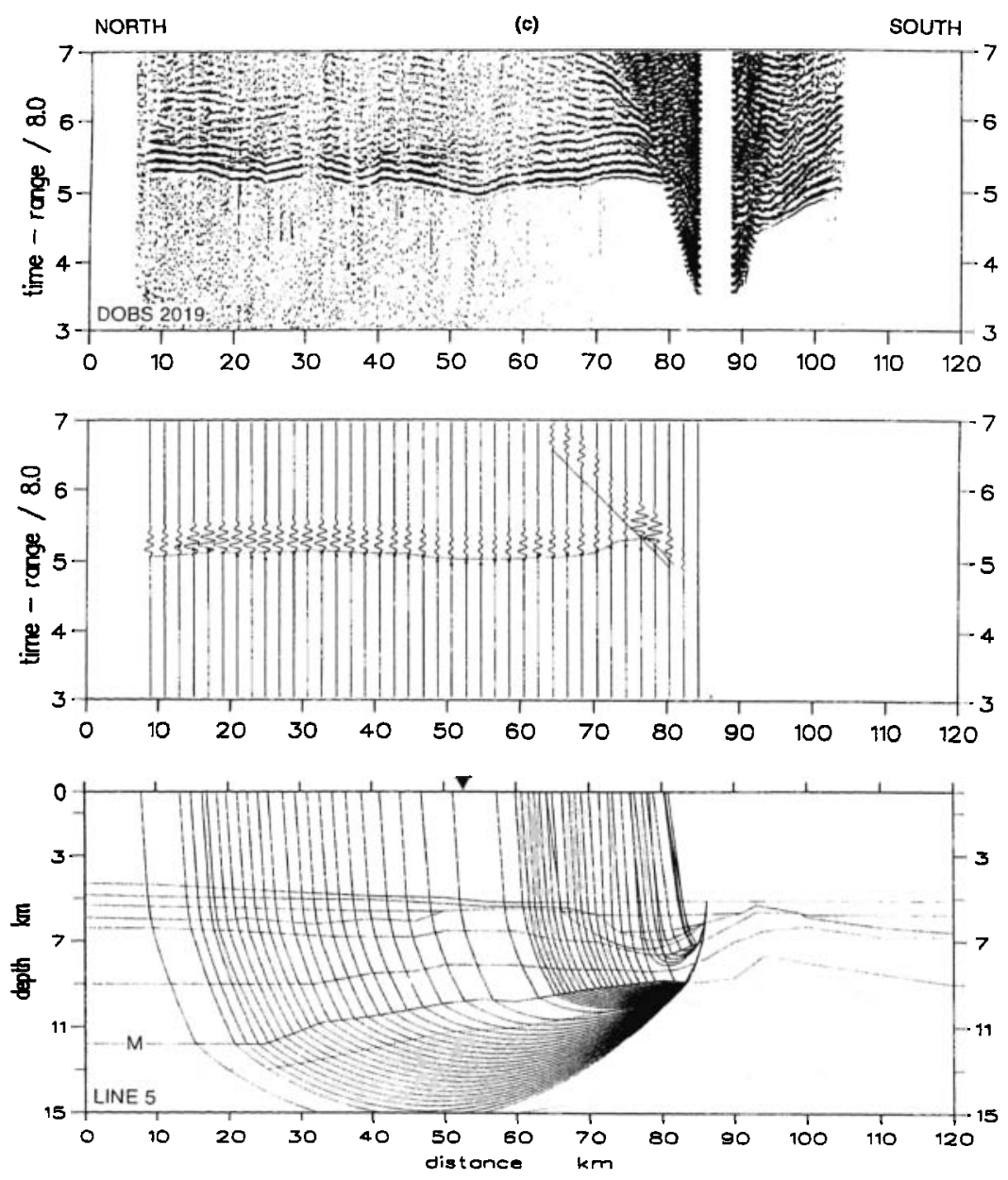

Figure 2. (continued)

be argued, using the same logic as for line 7E, that it indicates the existence of velocities of about $7.6 \mathrm{~km} \mathrm{~s}^{-1}$ near the base of crust.

\section{Line 8}

This westermmost, 80-km-long, margin-parallel line was shot over the flat seafloor of the Iberia Abyssal Plain. On the reflection profile, two sedimentary layers overlying an acoustic basement with up to $0.7 \mathrm{~s}$ relief are distinguished. The model is constrained by results from three DOBSs.

DOBS 4011 (Figure 4a). Strong lower crustal second arrivals are seen out to $80 \mathrm{~km}$ model range and support the existence of a Moho triplication, although the complexity of the hodochrons near the triplication suggests that interference of arrivals has made it difficult to match accurately the synthetic seismograms to the observations.

DOBS 5002 (Figure 4b). The observations of $P_{m} P$ phases at this DOBS in the center of the line support the existence of the Moho reflections detected by the other DOBSs.

DOBS 1019 (Figure 4c). This record section is atypical of our dataset in that there is evidence of second arrivals between 15 and $50 \mathrm{~km}$ model range. These have been modeled as part of the Moho triplication.

\section{Line 7EW}

The third, $30-\mathrm{km}$-long line shot in the vicinity of the peridotite ridge (here called line 7EW) was shot in an E-W direction across the ridge (Figure 1). It was recorded by two DOBSs (4010 and 4012), each situated about $15 \mathrm{~km}$ away on either side of the ridge outcrop. Modeling of the observations is also constrained by the fact that ODP Leg 103 drilled serpentinized peridotites with a velocity of $-3.5 \mathrm{~km} \mathrm{~s}^{-1}$ at Site $637,9 \mathrm{~km}$ farther north on the flank of the ridge [Goldberg and Zinszner, 1988]. The ridge was modeled by a steady increase in velocity from 3.5 down to about $7.5 \mathrm{~km} \mathrm{~s}^{-1}$ at a depth of $11 \mathrm{~km}$ (Figure 5). The structures on the flanks of the ridge were constrained by the intersecting lines $7 \mathrm{E}$ and $7 \mathrm{~W}$. The amplitudes of the observed traces are quite variable; the weaker first arrivals are largely caused by defocusing by the relief of the ridge. Although the structure on either side of the ridge is determined chiefly by lines $7 \mathrm{E}$ and $7 \mathrm{~W}$, the structure of the ridge itself above $12 \mathrm{~km}$ depth is constrained well by the reversed ray paths.

\section{Line 6}

The $150-\mathrm{km}$-long line 6 was shot normal to the Galicia Bank margin and was recorded by three DOBSs, of which one was situated just east of the peridotite ridge and the remainder were above tilted fault blocks higher up the margin. The seismic velocity model along this line was constrained by the results of the four intersecting lines described above and by the general form of the peridotite ridge in the model already fitted to line $7 \mathrm{EW} 15 \mathrm{~km}$ to the south. Travel times were harder to fit along this line, probably because of strong lateral variations in structure. 

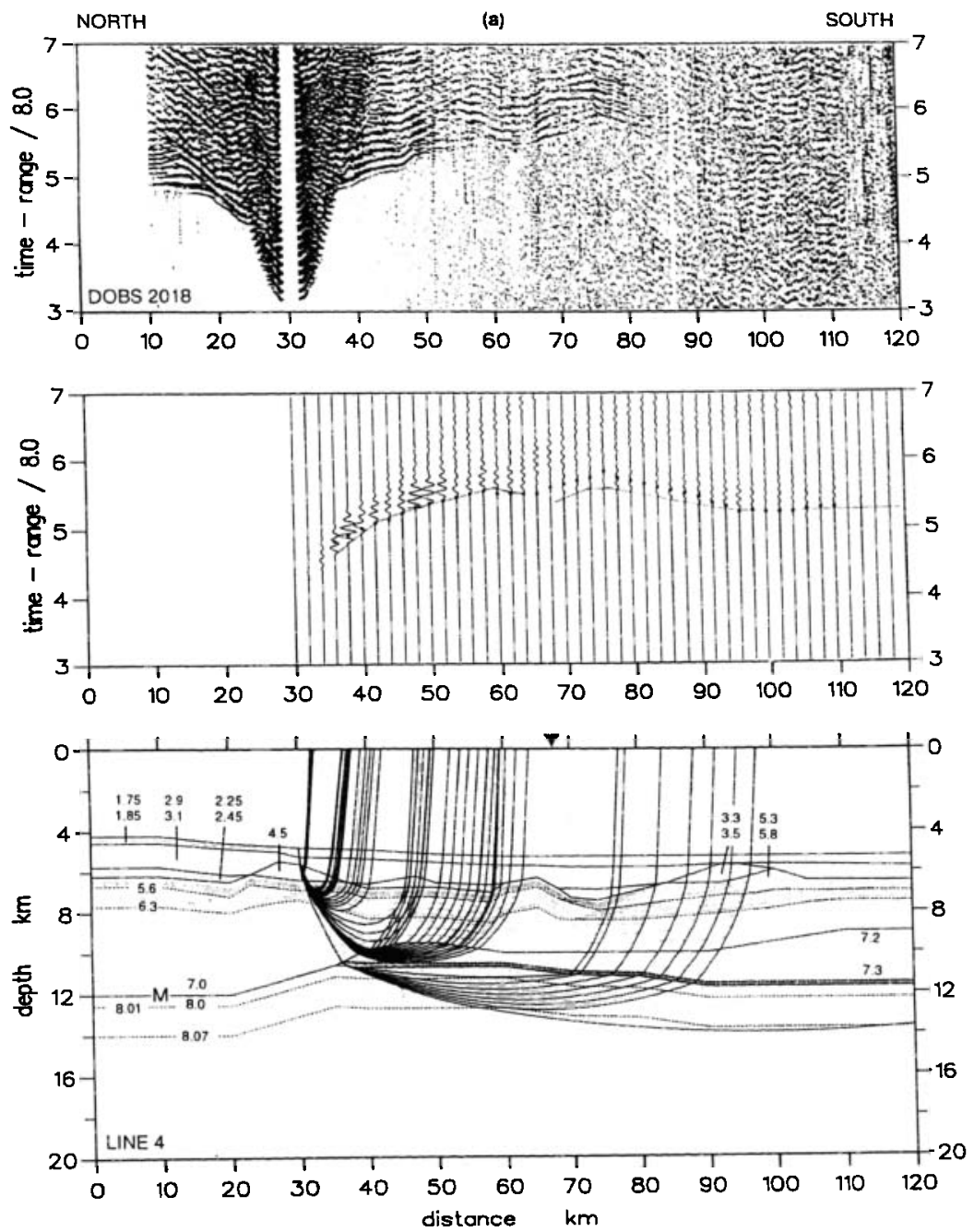

Figure 3. Variable area record sections, synthetic seismograms and ray diagrams for line 4. See Figure 2 caption for a full explanation of the parts of this diagram. (a) DOBS 2018, (b) DOBS 4007.

DOBS 4009 (Figure 6a). This record section has the best signal-to-noise ratio of the DOBSs along this line, probably the result of its location in deep water and over thick sediments. The travel time fluctuations due to basement relief are severe, yet the computed times fit to within $100 \mathrm{~ms}$, except around $120-125 \mathrm{~km}$ model range where the rays pass through a tilted fault block and a sediment pond which may not have been well imaged on the seismic profile. The principal amplitude variations are well matched except for the weak synthetics between 80 and $95 \mathrm{~km}$. The apparent travel time offset around $20 \mathrm{~km}$ model range west of the DOBS is caused principally by basement relief.

DOBS 1018 (Figure 6b). Except for 30 and $37 \mathrm{~km}$ model range, the arrivals fit to within about $100 \mathrm{~ms}$. The misfit between 30 and $37 \mathrm{~km}$, which coincides with rays crossing the peridotite ridge, is in the opposite sense to that of arrivals at DOBS 2020.

DOBS 2020 (Figure 6c). The signal-to-noise ratio is rather poor west of $70 \mathrm{~km}$ model range, where picks were made using three-trace running averages. The travel times fit within about $200 \mathrm{~ms}$, and the longer wavelength variations associated with the crustal fault blocks are well matched. The worst fit is over the peridotite ridge, a region of probable surong velocity gradients and lateral variations. $P_{m} P$ arrivals, visible as second arrivals around $100 \mathrm{~km}$ model range, are also modeled.

\section{Resolution of the Model}

The preferred model of line 6 is well constrained not only by the intersecting rays arriving at the three DOBSs along line 6 but also by the structures determined along four intersecting lines. In spite of the strong lateral variations along line 6 , it proved possible to match the structures at line intersections quite precisely (Figure 7).

The resolution of the preferred model was estimated by varying the velocities, and the depths of interfaces and gradient changes, to determine their effect on computed travel times and synthetic seismograms. Changing boundaries by $200 \mathrm{~m}$ or velocities by $0.1 \mathrm{~km} \mathrm{~s}^{-1}$ made a significant difference to the synthetic seismograms in terms of their travel times, amplitudes, and termination points for crustal arrivals within the continental crust. Similarly, the oceanic velocity structure is constrained such that boundaries appear to be correct within $\pm 200 \mathrm{~m}$ and velocities appear correct within $\pm 0.1 \mathrm{~km} \mathrm{~s}^{-1}$. Any larger changes resulted in a misfit of more than $150 \mathrm{~ms}$ in 

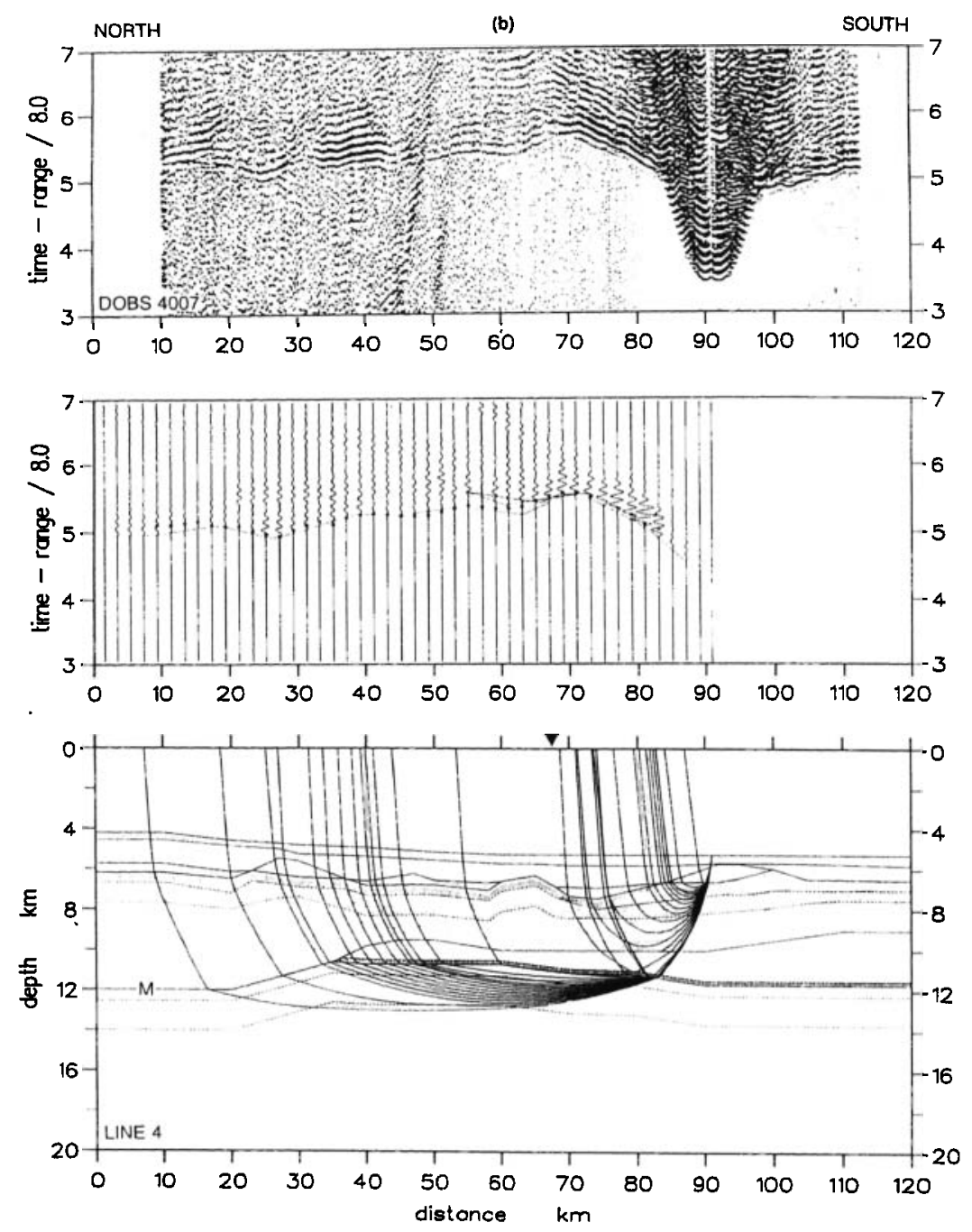

Figure 3. (continued)

arrival time. Similarly, the lower crustal and upper mantle velocities can be varied by only $\pm 0.1 \mathrm{~km} \mathrm{~s}^{-1}$ and the depth of the Moho can be varied by only $\pm 1 \mathrm{~km}$ before the travel time misfit is excessive.

\section{The Seismic Model of the Galicia Bank Margin}

The model has the following principal characteristics (Figures 6a and 7).

1. The sediments have been divided into a maximum of three layers, with velocities of 1.8-1.9, 2.2-2.5, and 2.5$2.7 \mathrm{~km} \mathrm{~s}^{-1}$, on the basis of reflectors recognized along line 6 , on reflection profile GP101, and on a profile collected during the Reframarge cruise. The deepest $2.5-2.7 \mathrm{~km} \mathrm{~s}^{-1}$ layer, from 45 to $9.5 \mathrm{~km}$ model range, probably represents synrift or older sediments [Mauffret and Montadert, 1987].

2. The Moho rises from a depth of $20 \mathrm{~km}$ below sea level in the east to a minimum of $10 \mathrm{~km}$ depth at $80 \mathrm{~km}$ model range and then deepens more gradually to $14 \mathrm{~km}$ depth. Between 20 and $80 \mathrm{~km}$ model range the Moho is overlain by a lens-shaped body with velocities of up to $7.6 \mathrm{~km} \mathrm{~s}^{-1 .}$. The velocity at the top of the eastern limb $\left(7.0 \mathrm{~km} \mathrm{~s}^{-1}\right)$ is significantly lower than the velocity at the top of the westem limb $\left(7.35 \mathrm{~km} \mathrm{~s}^{-1}\right)$. The shoalest part of the lens is capped by a 4-km-high triangular prism with a velocity of $3.5 \mathrm{~km} \mathrm{~s}^{-1}$ at the top underlain by a steep vertical velocity gradient from 4.0 to $6.9 \mathrm{~km} \mathrm{~s}^{-1}$; this corresponds to the peridotite ridge sampled both north and south of Line 6 [Boillot et al., 1987b, 1988b] and traversed by line 7EW. Therefore from a seismic viewpoint, the lens and the ridge can be interpreted as a single generic body characterized by steep vertical velocity gradients. This interpretation therefore implies that serpentinized peridotite extends vertically from the top of the ridge to the present Moho and laterally from 20 to $80 \mathrm{~km}$ model range just above the Moho. In contrast to our observations of $P_{m} P$ phases east and west of the lens, $P_{m} P$ phases are not seen from the base of the lens; this supports the interpretation of a small velocity contrast at the base of the lens (Figure 7) consistent with it representing the lower limit of serpentinization. The lens-shaped body is unlikely to be the result of underplating because of the lack of other evidence of significant synrift volcanism on this margin [Martins, 1991] and because velocities higher than $7.4 \mathrm{~km} \mathrm{~s}^{-1}$ are not easy to account for by this process other than by an ad hoc mixture of underplated and upper mantle material [Whitmarsh et al., 1993]. 

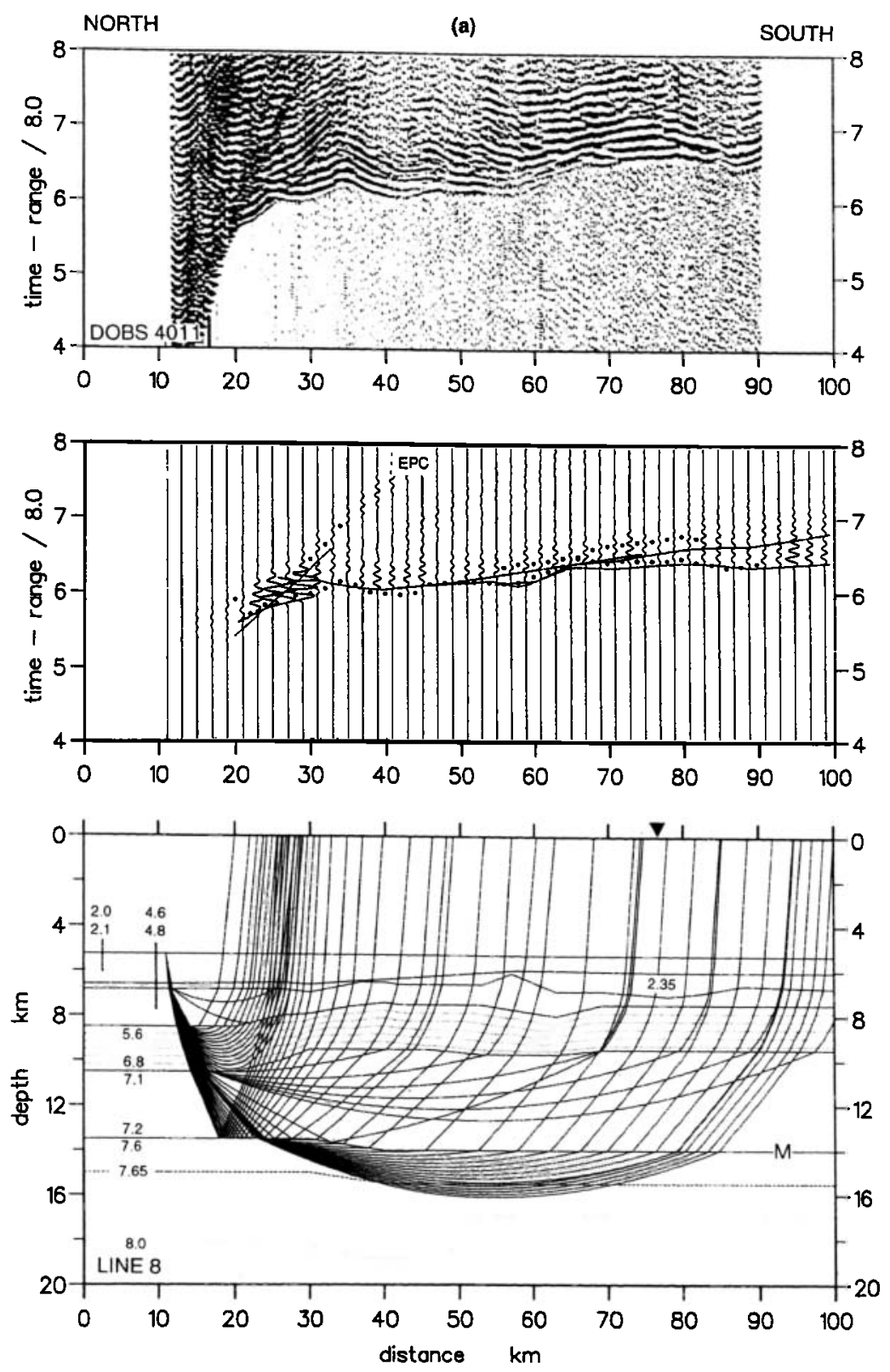

Figure 4. Variable area record sections, synthetic seismograms and ray diagrams for line 8. See Figure 2 caption for a full explanation of the parts of this diagram. (a) DOBS 4011, (b) DOBS 5002, (c) DOBS 1019.

3. Implicit in the recognition of the serpentinized peridotite body discussed above is the fact that the thickness of the crust of continental origin (including prerift sediments) decreases from $17 \mathrm{~km}$ in the east to $2-3 \mathrm{~km}$ immediately east of the peridotite ridge. The velocity in the continental crust increases steadily with depth (Figure 7) from 4.0 to $7.0 \mathrm{~km} \mathrm{~s}^{-1}$, similar to many other velocity models of continental crust which has been extensively stretched and thinned [Whitmarsh et al., $1986,1990]$. There is no evidence for a midcrustal Conrad discontinuity, even in the thickest crust, as was also true for the Goban Spur margin beneath the Southwest Approaches to the English Channel [Horsefield et al., 1994].

4. If, at the time of breakup, the serpentinized peridotite lens was part of the upper mantle, then the crust immediately west of the peridotite ridge, from 23 to $40 \mathrm{~km}$ model range, was only $2.5-3.5 \mathrm{~km}$ thick. At about $20 \mathrm{~km}$ model rarige the crust thickens rapidly to $7-8 \mathrm{~km}$ and exhibits the structure and thickness of normal oceanic crust at the westem end of line 6 (Figure 7 [White, 1992b]). The velocity structure of the 2.5- to $3.5-\mathrm{km}$-thick crust is similar to that of the crust immediately to the east of the ridge, but we attach little significance to this (velocity invariably increases in the top few kilometers of the igneous-metamorphic crust irrespective of the petrology involved). Synrift sediments, which overlie only the thinned continental crust, are absent west of the peridotite ridge [Groupe Galice, 1979; Mauffret and Montadert, 1987]. Further, a deep-towed magnetometer profile along line 6 shows a dramatic reduction in magnetic anomaly amplitude from west to east across the peridotite ridge, and modeling strongly suggests that the western crust has a magnetization of 

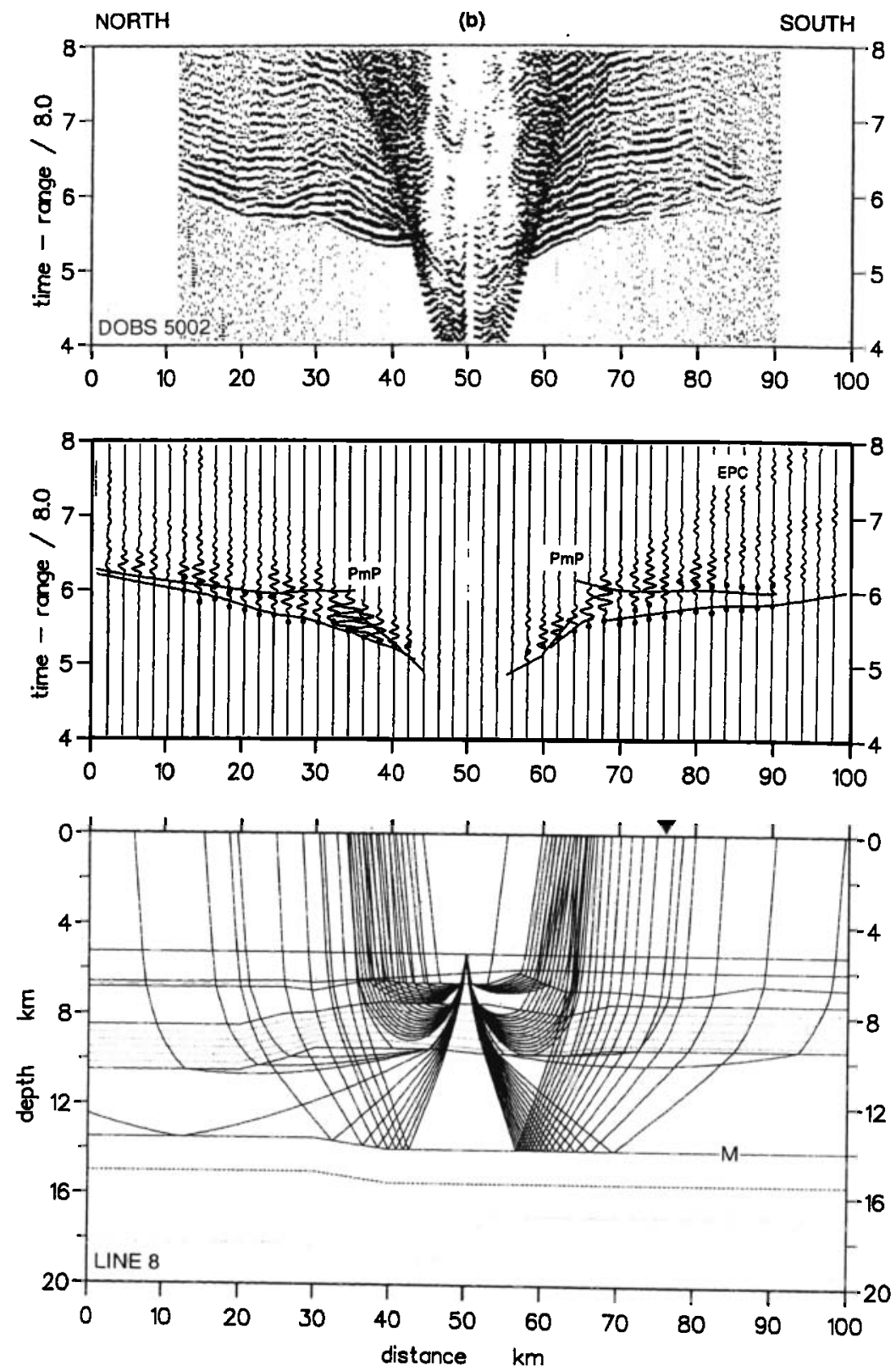

Figure 4. (continued)

$5 \mathrm{~A} \mathrm{~m}^{-1}$, at least several times that of the crust immediately east of the ridge [Sibuet et al., 1995]. We therefore propose that the $2.5-$ to $3.5-\mathrm{km}$-thick crust is simply the product of initial seafloor spreading when the magma supply was limited due to conductive cooling of the ascending mantle during the long (25 m.y.) stretching phase of the continental margin [White, 1992b; Whitmarsh et al., 1993; Bown and White, 1995a]. After seafloor spreading had created $15-20 \mathrm{~km}$ of oceanic crust (e.g., for $2 \mathrm{~m} . \mathrm{y}$. at $10 \mathrm{~mm} \mathrm{yr}^{-1}$ ) the spreading center had moved away from the cooled asthenospheric mantle, a "steady state" was achieved, and normal thickness oceanic crust was produced.

\section{Comparison of Reflection and Refraction Results}

MCS reflection profiles across the Galicia Bank margin [Groupe Galice, 1979; Mauffret and Montadert, 1987;
Reston et al., 1996] provide a clear picture of the tilted basement fault blocks, generated as the margin rifted, and of the synrift and postrift sediments that fill the intervening graben and bury the fault blocks (Figure 8a). Below the fault blocks the main feature imaged by the MCS profiles is the $S$ reflector. Although this reflector appears fragmented on time sections, when the MCS profiles are enhanced by prestack migration and converted to depth sections they show that the $S$ reflector is continuous and almost linear across the outer 50 $\mathrm{km}$ of the continental margin [Hoffman and Reston, 1992; Reston et al., 1996]. $S$ is widely interpreted as a detachment surface at the base of the tilted fault blocks [de Charpal et al., 1978; Boillot et al., 1988a; Sibuet, 1992; Hoffman and Reston, 1992; Reston et al., 1996], and we concur with this view. It has not proved possible, thus far, to image the Moho discontinuity over more than a few kilometers on these MCS profiles. There is no indication of the lower crustal layering visible on other rifted continental margin profiles, such as the 

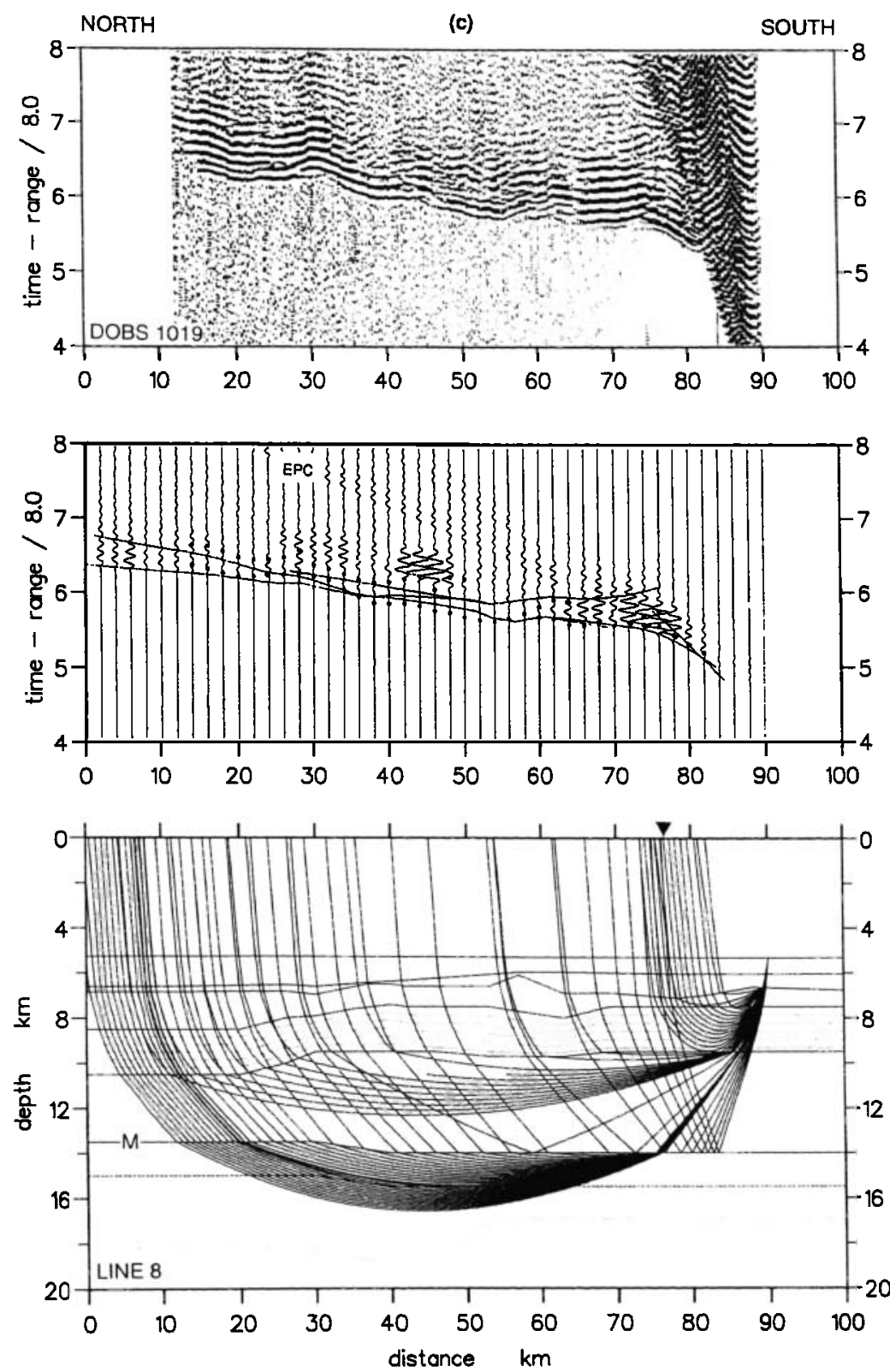

Figure 4. (continued)

WAM line across Goban Spur farther north in the Atlantic [Peddy et al., 1989; White, 1992b]. This may be due to the limited penetration of the existing MCS profiles and should not be taken necessarily as indicating that lower crustal layering is absent here. However, even so, on the recently acquired deep MCS profile IAM-11 [Banda et al., 1995] Moho reflections appear only beneath the tilted block located between 95 and $105 \mathrm{~km}$ in the model, and no lower crustal layering is observed.

Thus the seismic refraction results provide evidence that complements the MCS profiles. In particular, they enable the location of the $S$ reflector, picked from the time section of MCS profile GP101, to be compared directly with the crustmantle transition at the time of rifting (before serpentinization), which is well constrained across the continental margin. On GP101, $S$ is a very energetic reflector in its westem part between 50 and $65 \mathrm{~km}$ in the model, but faint and discontinuous reflections characterize $S$ east of 70 $\mathrm{km}$. The preferred line 6 velocity-depth model has been converted to two-way travel time to enable comparison with the $S$ reflector (Figure 8b). The following points are evident:

1. The energetic portion of $S$ corresponds, within $0.5 \mathrm{~s}$, to the top of the layer interpreted to be serpentinized peridotite. A small positive velocity contrast at this level could explain why $S$ is a simple reflector with a positive polarity on the MCS profile (as it is on adjacent profile GP12 [Krawczyk and Reston, 1995; Reston et al., 1995; Restom, 1996]). East of 70 $\mathrm{km}$ in the model, the $S$ reflector cuts across the lower part of the thinned continental crust and disappears somewhere in the midcrust. Therefore, like Winterer et al. [1988] and Reston et al. [1966], we interpret $S$ to be a top-to-the-west detachment fault.

2. The velocity contrasts in the seismic refraction model in the vicinity of $S$ do not explain why $S$ is a stronger reflector at 

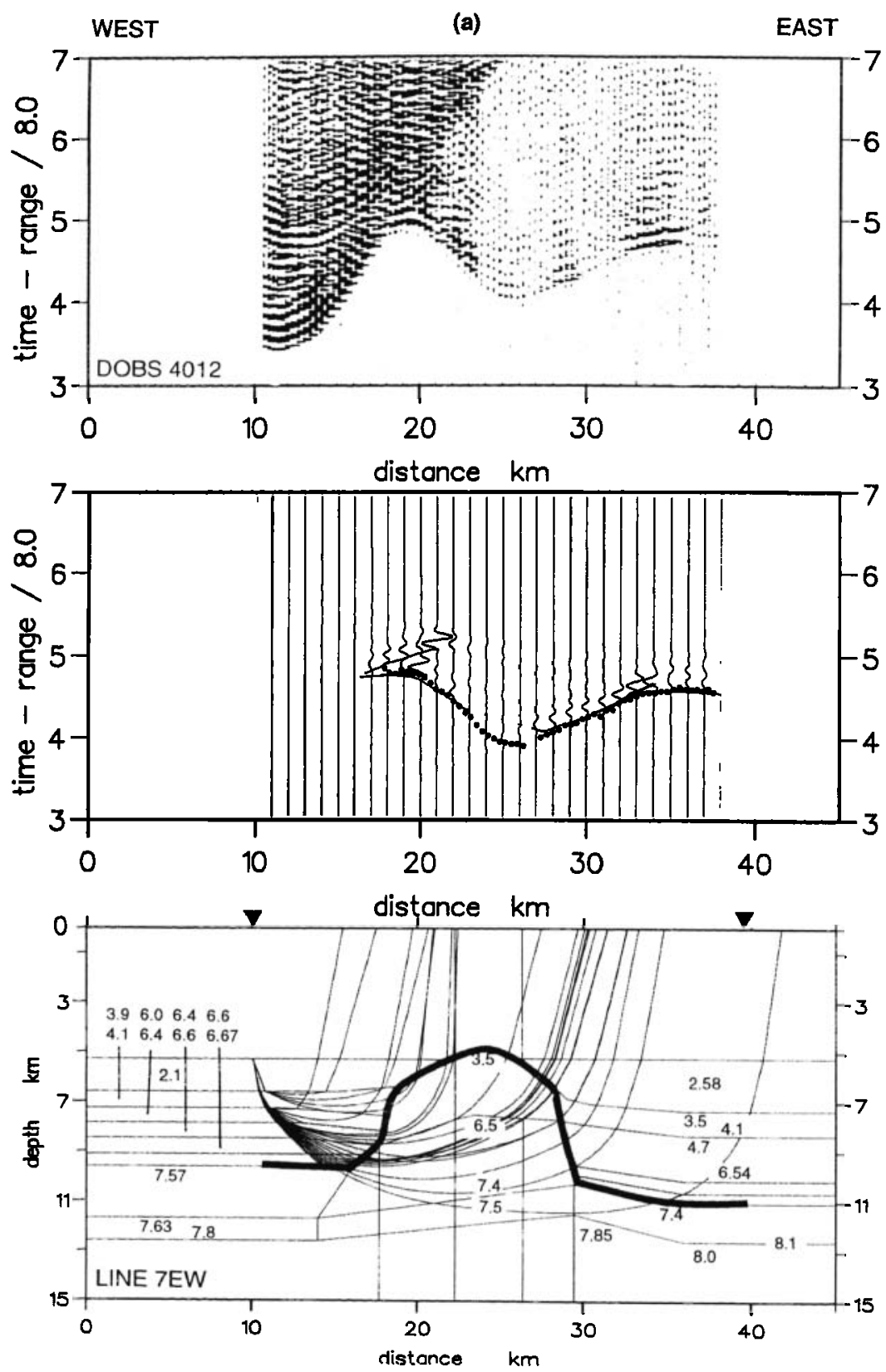

Figure 5. Variable area record sections, synthetic seismograms and ray diagrams for line 7EW. See Figure 2 caption for a full explanation of the parts of this diagram. The top of the serpentinized peridotite body is accentuated by the bold line. Lines $7 \mathrm{~W}$ and $7 \mathrm{E}$ intersect at the solid arrows. All the model segments at the base of the peridotite ridge (below $\sim 10 \mathrm{~km}$ and between 14 and $29.5 \mathrm{~km}$ ) have the same velocity structure. (a) DOBS 4012, (b) DOBS 4010.

the top of the serpentinized peridotite body than it is within the thinned continental crust. The explanation may lie in the 3 -times-shorter wavelength of the reflected energy and in the fine velocity structure of the shear zone represented by the $S$ reflector. It seems plausible that over distances comparable to the $-60-\mathrm{m}$ quarter wavelength of the reflected $25-\mathrm{Hz}$ signal, larger and more abrupt changes in lithology, and therefore velocity, are likely to be encountered near the original crustmantle boundary than within the thinned continental crust.

3. The fact that $S$ becomes a midcrustal reflector in its eastern part renders almost impossible the subsequent seafloor exposure of serpentinized peridotites, to form the peridotite ridge, by a process of tectonic denudation, with $S$ acting as a top-to-the-west detachment fault. This is a good demonstration of the fact that deep crustal reflectors imaged on MCS profiles cannot be interpreted confidently without the benefits of a velocity structure derived from modeling wideangle seismic refraction data.

\section{Gravity Modeling}

A gravity profile along line 6 (Figure 9) was constructed from data that were acquired during the $\mathrm{R} / \mathrm{V}$ l'Atalante ZEEGASC cruise in 1992 and, for the westermmost $38 \mathrm{~km}$, 

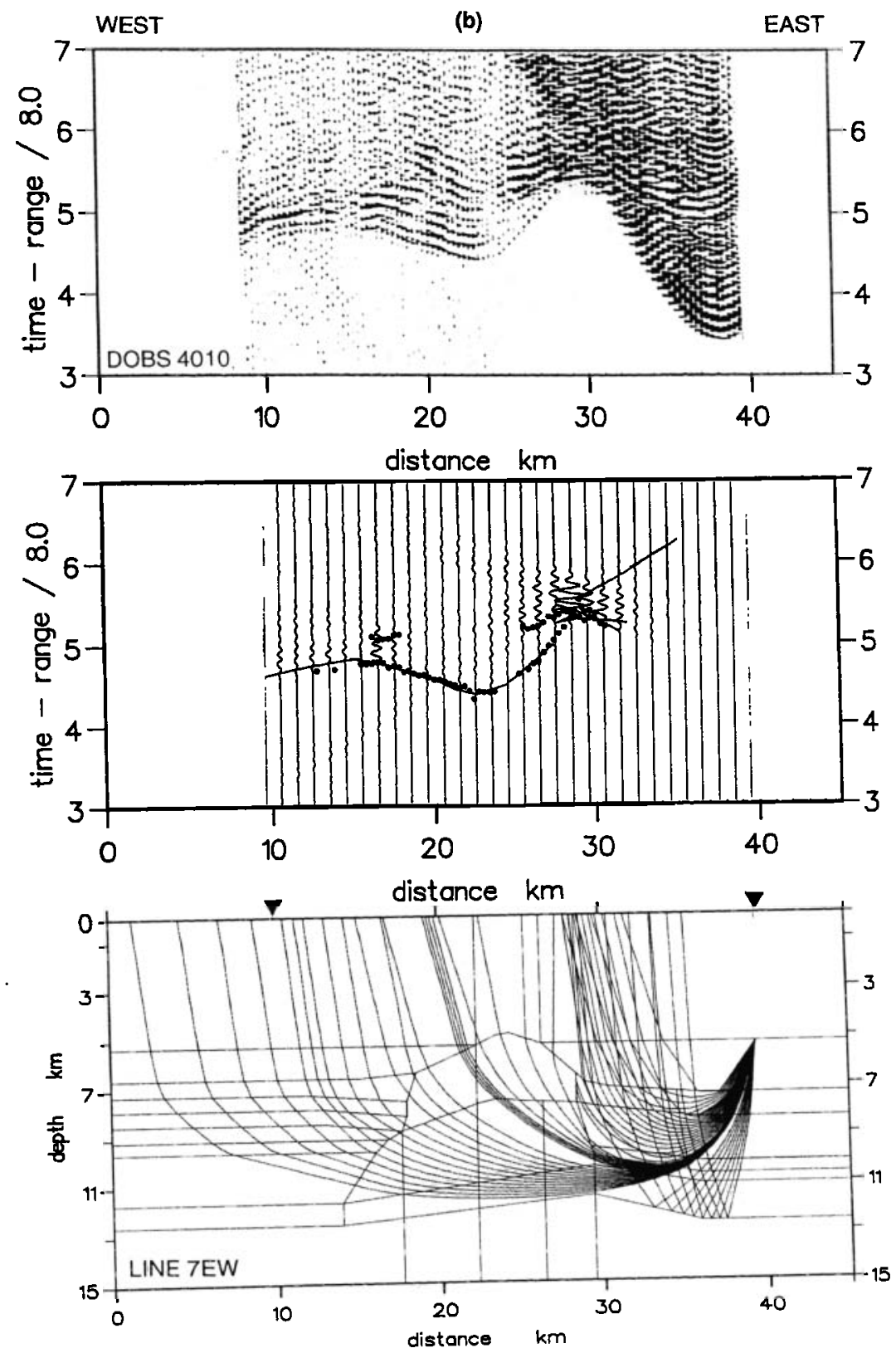

Figure 5. (continued)

from data that were extracted from the northeast Atlantic gravity map of Lalaut et al. [1981]. The seismic model (Figure 7) was converted to a density model using Barton's [1986] tables for sediments and continental crust, and the following relationship of Carlson and Henrick [1990] for oceanic crust:

$$
p=(3.81 \pm 0.02)-(5.99 \pm 0.11) \mathrm{V}_{\mathrm{p}}^{-1}
$$

where $\rho$ is density in megagrams per cubic meter and $V_{p}$ is seismic velocity in kilometers per second.

The water column and mantle were assigned densities of 1.03 and $3.30 \mathrm{Mg} \mathrm{m}^{-3}$, respectively. The blocks of the velocity model, which delineate bodies in which velocity variations are a linear function of depth, provided a first-order constraint on the density models. To achieve a good $( \pm 10 \mathrm{mGal})$ fit to the observed free-air anomaly (Figure 9) it was necessary to adjust the densities of the lower continental and oceanic crusts by up to $0.05 \mathrm{Mg} \mathrm{m}^{-3}$. The load anomaly across the density model, which in the initial models increased slightly toward the continent (by $2 \times 10^{3} \mathrm{Mg} \mathrm{m}^{-2}$ ), became essentially constant along the whole profile after the lower crustal densities were adjusted.

The margin is close to isostatic equilibrium, with local outof-balance stresses of about $2 \times 10^{3} \mathrm{Mg} \mathrm{m}^{-2}(200 \mathrm{kPa})$, which can be sustained by the crust. It is always possible to make computed and observed gravity profiles fit better by slightly modifying lower crustal densities and/or the shape of the Moho within the $\pm 1-\mathrm{km}$ range that can be tolerated by the seismic modeling. However, this would have no geological significance, as the simple gravity model in Figure 9 already shows that the margin is close to isostatic equilibrium and that the seismic model is consistent with the gravity observations. 

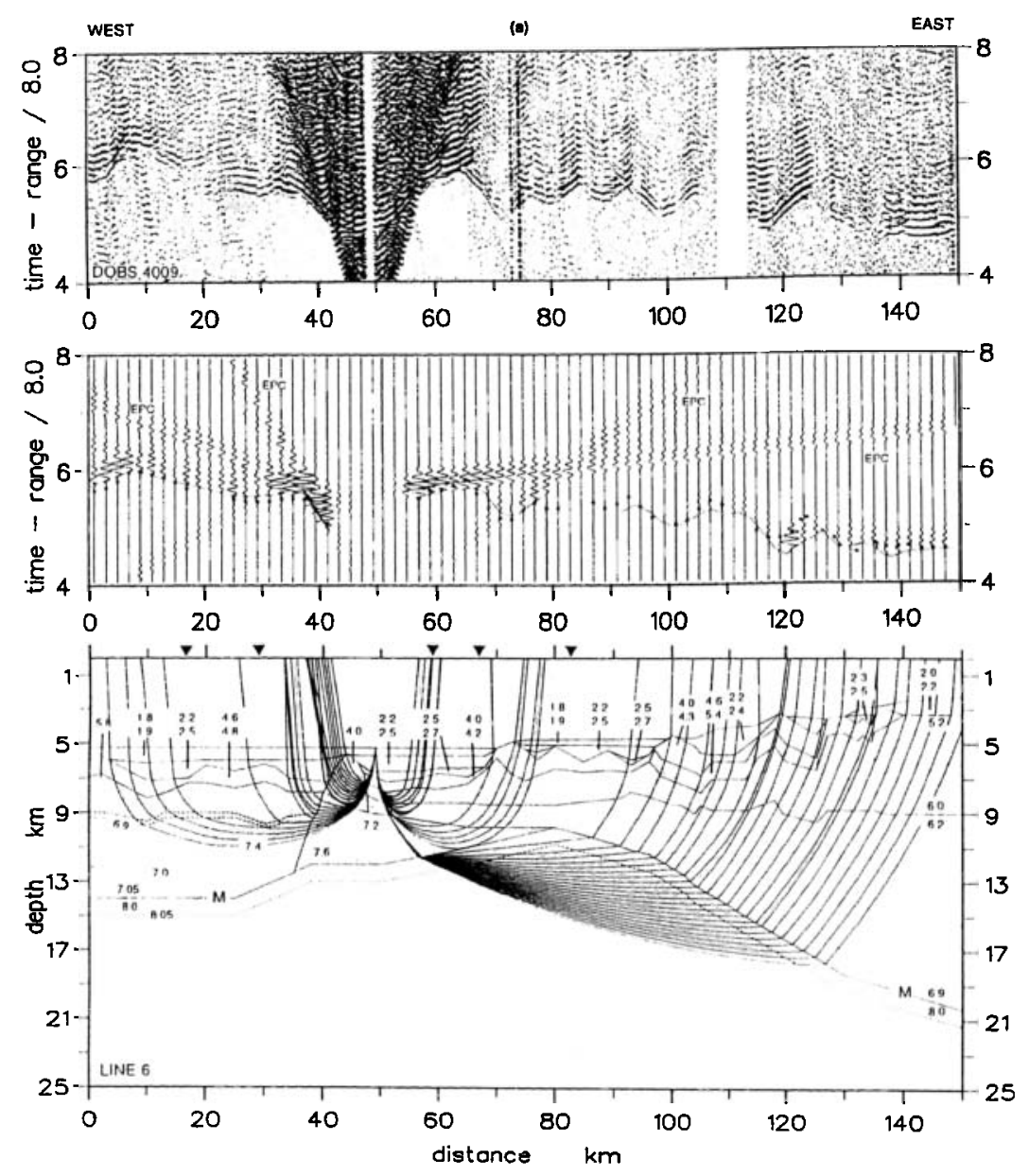

Figure 6. Variable area record sections, synthetic seismograms and ray diagrams for line 6. See Figure 2 caption for a full explanation of the parts of this diagram; $P_{m} P$ indicates Moho reflections. The intersections with the other Reframarge lines are shown by solid arrows. The peridotite ridge is the basement high at $45 \mathrm{~km}$ in the model. (a) DOBS 4009, (b) DOBS 1018, (c) DOBS 2020.

\section{Numerical Models of Melt Generation and Subsidence}

The seismic and gravity data discussed above constrain the variation of crustal thickness across the Galicia Bank continental margin, and provides a broad indication of how the crustal type changes from being moderately thinned continental to fully oceanic. In the following sections we discuss the inferences that can be drawn about the evolution of the rifted margin from the amount of igneous rock that is generated during the rifting and from the subsidence history.

\section{Pure or Simple Shear?}

This continental margin is often cited as one where simple shear may play a significant role in the deformation. The primary evidence for this is the presence of the $S$ reflector [Krawczyk and Reston, 1995; Reston et al. 1995, 1996] in the middle and lowermost crust; there is no cvidence on reflection profiles for detachments cutting through the entire lithosphere. It is clear that in the upper part of the crust the deformation is achieved by block faulting and low angle detachments rather than by pure shear. This form of deformation is most marked in the outer portion of the continental margin. Closer to the unstretched continent, where stretching factors are small, bulk pure shear is probably the best description of the lithospheric deformation. At the oceanic spreading center, pure shear provides a good long-term description of the extension. However, even in the intervening region of the margin where there is clear evidence of upper crustal detachments, we assume that bulk pure shear is still a good approximation of the overall lithospheric deformation [Sibuet et al., 1995].

\section{Mantle Melting Model}

In the extensional models that we use here, we assume that the lithosphere is thinned by bulk pure shear. This is a good approximation in the areas of small extension (landward end of the continental margin) and of very high extension (oceanic crust); since most of the melting occurs in the region of the mantle that rises to shallowest depths immediately beneath the lithospheric lid, it is a reasonable assumption that bulk thinning of the lithosphere is a good approximation in the lower portion of the margin as well. A significant component of lithospheric simple shear would change the melt distribution somewhat between the upper and the lower plates [Latin and White, 1990], but since there is no hard evidence here for lithospheric-scale simple shear, we restrict our discussion to pure shear. 

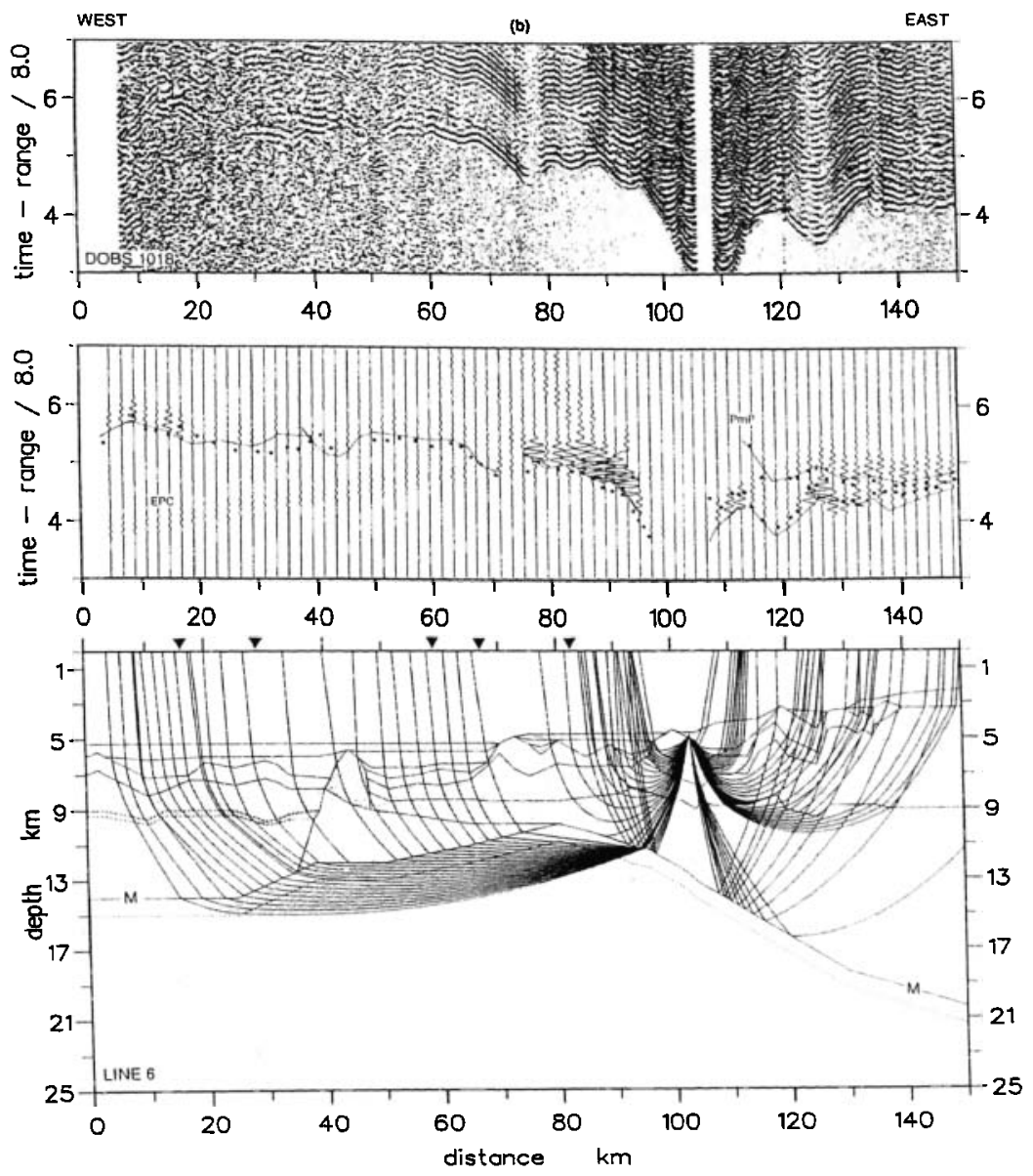

Figure 6. (continued)

The melting and subsidence model we use here is described by Bown and White [1995a, b]. We assume dry mantle melting, with the equations for the conservation of mass, momentum, and energy given by McKenzie [1984]. Although melt generation within the mantle may be described better by fractional melting than by batch melting, all the experiments which define the relationships between temperature, pressure, melt fraction, and melt composition are batch-melting experiments. Nevertheless, predictions of both the thickness and the bulk composition of oceanic crust have been successful using the batch melting experimental data [McKenzie and Bickle, 1988]. We therefore use a similar approach in our calculations.

We calculate the thermal evolution of the margin and the melt generation processes in two stages. First we calculate the temperatures, ignoring the thermal consequences of melting but with allowance for heat loss due to thermal conduction during finite-duration rifting. Second, we correct these temperatures for the absorption of latent heat of fusion by the melting process, using the same technique as that of Watson and McKenzie [1991], but with a value of $400 \mathrm{~J} \mathrm{~kg}^{-1}{ }^{\circ} \mathrm{C}^{-1}$ for the entropy of fusion rather than the value of $250 \mathrm{~J} \mathrm{~kg}^{-1}{ }^{\circ} \mathrm{C}^{-1}$ that they adopted. We also include the effect of mantle compaction caused by the extraction of melt, a factor neglected by McKenzie and Bickle [1988].

The strong dependence of the duration of extension on the amount of melt generated by continental rifting was demonstrated first by Pedersen and Ro [1992]. The main difference between their models and ours is that they use a simpler description of the melting of anhydrous mantle rocks published by Ahern and Turcotte [1979]; this results in considerably less melt being produced by our model than by Pedersen and Ro's, with a more rapid decrease in melt volume from our model as the duration is increased. Keen et al. [1994] have also considered the effect on melt generation of rifting episodes spread over a long duration, although in their study they modeled the extension as a series of discrete, instantaneous rift events rather than by the continuous rifting we model. Again, they found that rifting spread over a long period decreased the amount of melt generation from the mantle as it decompressed.

\section{Factors Controlling Melt Generation and Subsidence}

Four main factors are important in the generation of melt by dry mantle during decompression. These are the stretching factor, the potential temperature of the mantle, the duration of the stretching event, and the original lithosphere thickness [Bown and White 1995a].

We calculate the stretching factor of the lithosphere from the crustal thickness, assuming as discussed above that the lithosphere deforms by bulk pure shear. Where little or no melt is generated, as at the landward end of the profile, the ratio of the initial to the final crustal thickness thus provides a 

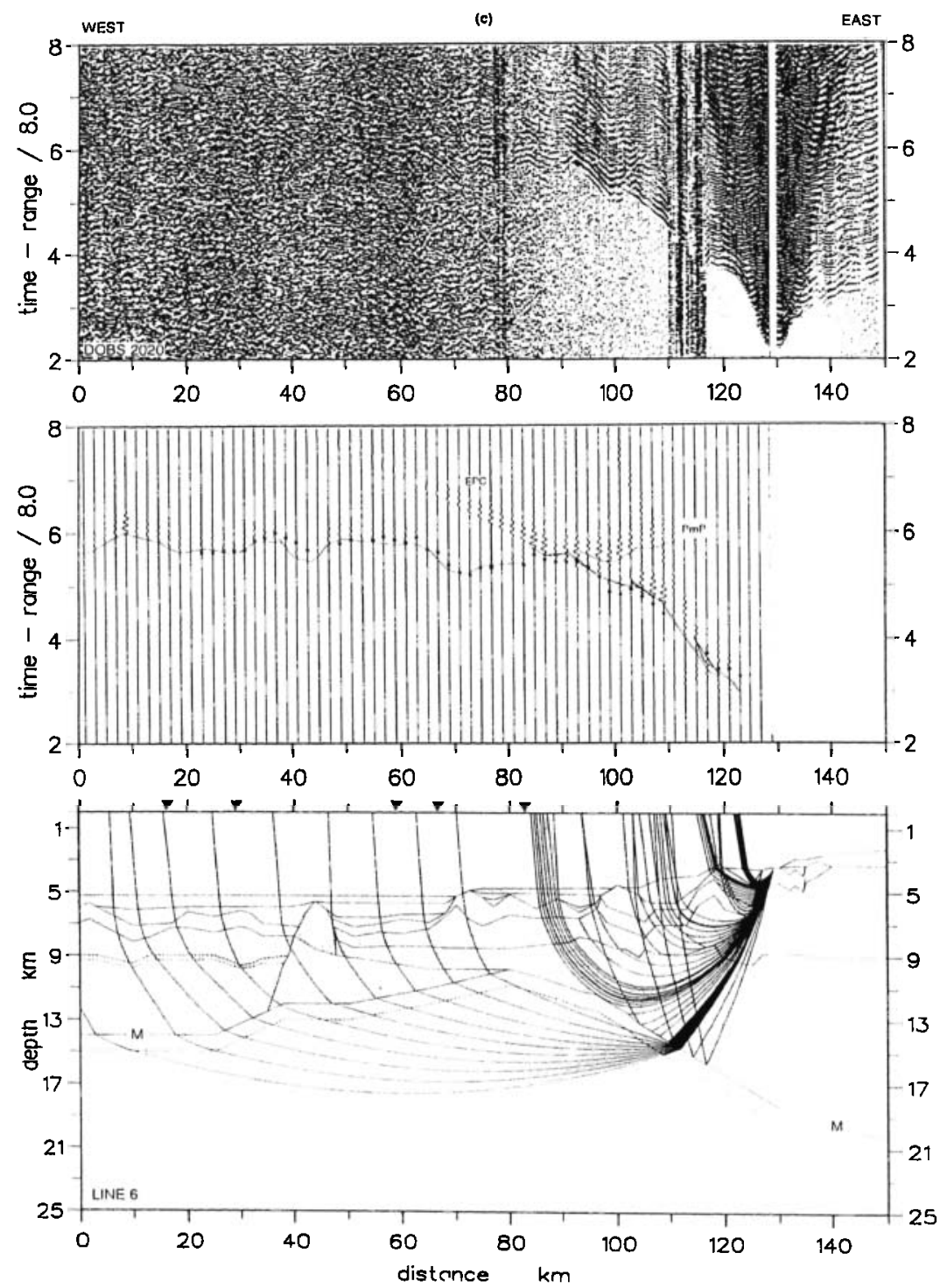

Figure 6. (continued)

measure of the stretching factor beta. As the oceanic end of the profile is approached, the increasing volume of synrift igneous rock means that the final crustal thickness may be greater than that due to thinning by extension alone. We take account of this by calculating in our modeling the melt generated as a function of the stretching factor.

Subject to the experimental uncertainty discussed earlier, we calculate the crustal thickness from the depth to the Moho (i.e., the depth at which the $P$ wave velocity exceeds $7.6 \mathrm{~km} \mathrm{~s}^{-1}$ ). However, the inference of crustal rock type from velocity alone is more uncertain because many different rock types can exhibit similar velocities. So although it is clear from dredged rocks that the tilted fault block $30 \mathrm{~km}$ east of the peridotite ridge contains rocks typical of continental crust [Mamet et al., 1991], while the crust west of the peridotite ridge has a velocity structure and magnetization typical of oceanic crust, we cannot be sure what proportion, if any, of the continental crust east of the peridotite ridge is igneous material emplaced during extension. For a moderate stretching factor of about 4, such as is found near the landward end of the profile, it is probable that little or no melt is generated, but as stretching factors exceed 5 near the seaward edge of the
OCT, then, subject to other factors discussed below, increasing amounts of melt are likely to be generated. To the west of the peridotite ridge we expect that the oceanic crust consists entirely of melt produced by mantle decompression melting beneath an oceanic spreading center.

The potential temperature of the parent mantle is important because more melt is generated from hotter mantle [McKenzie and Bickle 1988; White and McKenzie, 1989]. On the Galicia Bank margin there is no evidence for hotter-than-normal mantle at the time of continental breakup or subsequently. Indeed, the oceanic crustal thickness of $-7 \mathrm{~km}$ that is found at the western end of the profile, well beyond the OCT, is typical of normal mantle found elsewhere around the world with a potential temperature of $1300^{\circ} \mathrm{C}$ [White et al. 1992]. In the numerical modeling that follows we therefore adopt a normal mantle potential temperature of $1300^{\circ} \mathrm{C}$. Louden et al. [1991] have suggested that the mantle may have been about $100^{\circ} \mathrm{C}$ cooler than normal (i.e., potential temperature of $1200^{\circ} \mathrm{C}$ ), but as we discuss later, we think this unlikely because at such temperatures only $\sim 1 \mathrm{~km}$ of igneous crust would be generated at the oceanic spreading center.

The duration of the stretching has a marked effect on the 

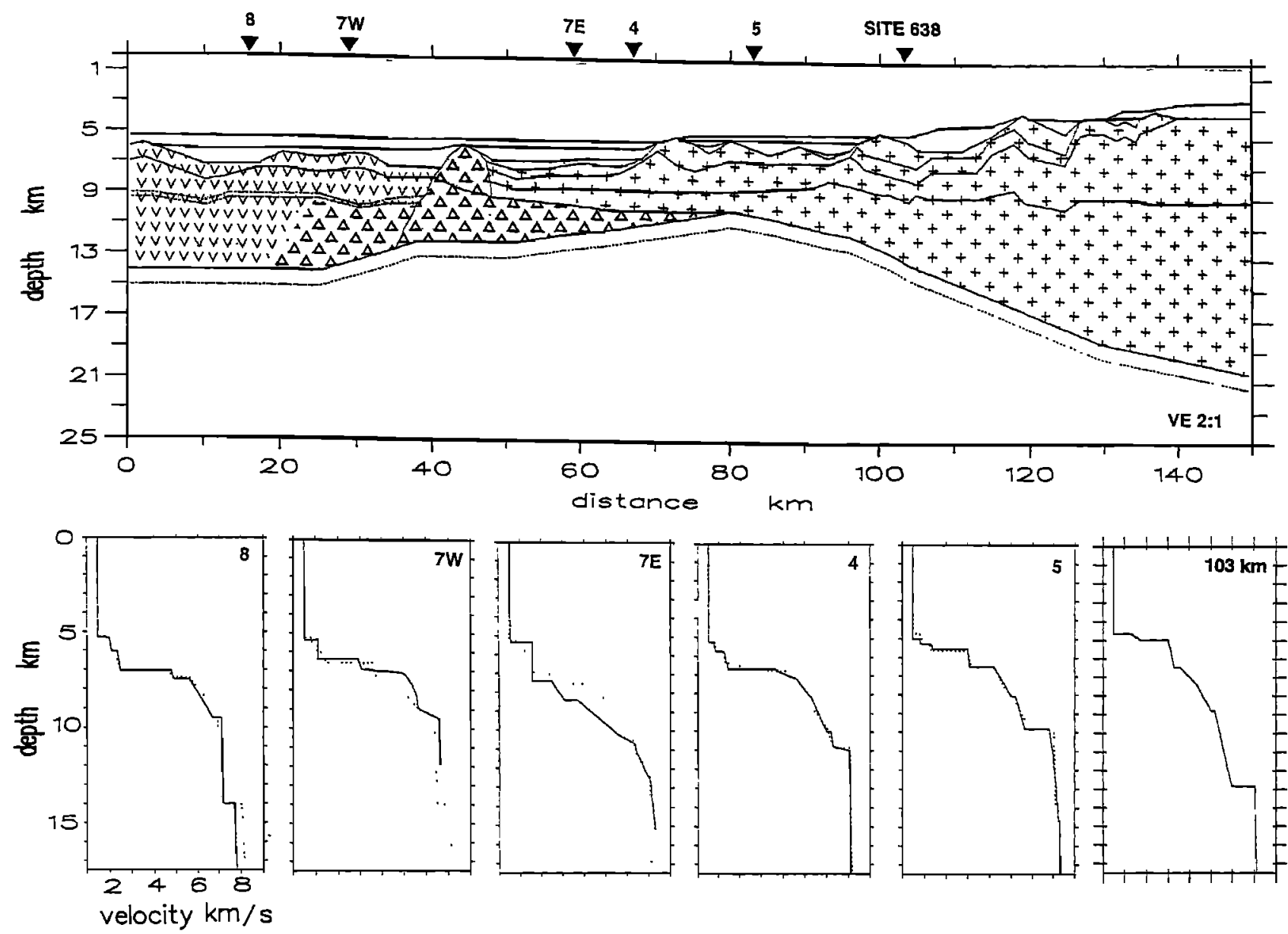

Figure 7. Line 6 velocity model with velocity-depth profiles (dotted for Line 6 profiles) at the interseclions of refraction lines $8,7 \mathrm{~W}, 7 \mathrm{E}, 4$, and 5 and beneath ODP Site 638 at $103 \mathrm{~km}$ in the model (locations are indicated by inverted triangles). The symbols indicate the interpreted extents of oceanic crust ( $v$ symbols), continental crust (plus signs) and serpentinized peridotitc (triangles).

amount of melt that is generated [Pedersen and Ro, 1992; Bown and White, 1995a,b]. If stretching lasts 10 m.y. or more, much less melt is generated than for instantancous stretching because the upwelling mantle cools by conduction as it rises beneath the thinning lithosphere. On continental margins such as Galicia Bank, the synrift sediments show that stretching often does persist over many millions or tens of millions of years, so this is an important characteristic which our model reproduces. The initial lithospheric thickness also affects the total volume of melt generated; we assume a normal prerift lithospheric thickness of $125 \mathrm{~km}$.

On the Galicia Bank margin, independent constraints on the subsidence history are available from ODP sites. In the following sections we discuss the evidence for melt gencration and crustal thinning (both are constrained by the seismic velocity model and subsidence data) and use numerical models of melting and subsidence at rifts to investigate the amount and duration of rifting across the Galicia Bank margin.

We divide the ocean-continent profile into four representative sections for our discussion. The first section, toward the landward end $(100-110 \mathrm{~km}$ in Figure 7$)$ is characterized by moderate continental extension (beta values of 4 to 5 ) and is constrained by the synrift and postrift subsidence history of ODP Sites 638, 639 and 641 (Figures 7 and 8) [ODP Leg 103 Shipboard Scientific Party, 1987; Moullade et al., 1988]. The second section is at the foot of the continental slope (45-70 km in Figure 7) where highly attenuated, and possibly intruded, continental crust lies within, and adjacent to, the OCT. The third area $(20-35 \mathrm{~km}$ in Figure 7) lies just on the oceanic side of the OCT, and exhibits unusually thin oceanic crust. The final area is normal thickness oceanic crust found at the most oceanward end of the profile $(0-15 \mathrm{~km}$ in Figure 7$)$.

\section{Subsidence of the Continental Crust at the Landward End of the Profile}

In the vicinity of ODP Sitcs 638,639 , and 641 the postrift subsidence history of the margin is constrained by the sedimentary sequence [Mauffret and Montadert, 1988; Moullade et al., 1988]. The crustal thickness in this part of the seismic refraction profile is also well constrained by both mantle diving rays and by reflections off the Moho (Figures 6 and 7). Excluding the postrift sediments, the crustal thickness beneath the ODP sites averages $7.5 \mathrm{~km}$.

Assuming pure-shear stretching, the measured $7.5-\mathrm{km}$ crustal thickness can be translated into a stretching factor, provided that the initial prerift crustal thickness is known. The 

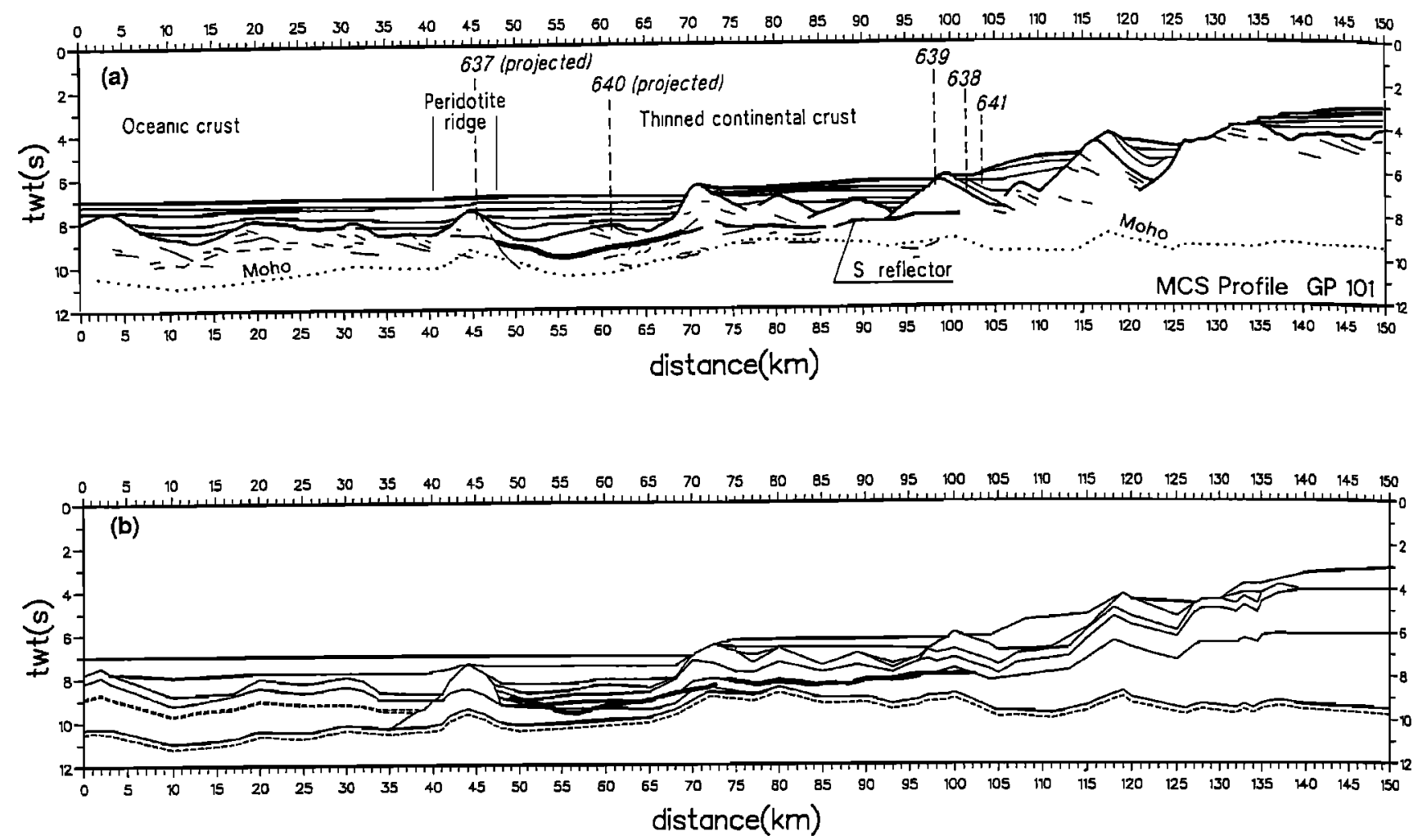

Figure 8. (a) Time migrated section of multichanncl seismic profile GP101, which is coincident with line 6 (from Figure 2 of Sibuet et al. [1995], with kind permission of Kluwer Academic Publishers, based on the latest reprocessing of this line by the Institut Français de Petrole). The bold subhorizontal line is the $S$ reflector and has been thickened where $S$ is scen to be particularly strong. (b) Time section based on the preferred velocity model along line 6 with the $S$ reflector from Figure 8a superimposed.

unstretched crustal thickness of NW Ibcria is about $32 \mathrm{~km}$ [Cordoba et al., 1987]. The overall stretching factor in this region of the continental margin is thus 4.3 .

The average stratigraphic column in the vicinity of the ODP holes reported by Boillot and Winterer [1988], together with paleodepth estimates from Mauffret and Montadert [1988] and Moullade et al. [1988], have bcen used to calculate the water-loaded basement subsidence history by backstripping the sediments, assuming local isostasy. Because the Galicia Bank margin has not been heavily sedimented, the uncerlainty in the water-loaded subsidence is govemed largely by the uncertainty in the paleobathymetry at the time of sediment deposition. The main causes of uncertainty in the paleobathymetry are the lack of precision of the biostratigraphic markers and the possibility that some of the sediments have been reworked by downslope movement, so that they were deposited in greater water depths than those indicated by the fossils they contain. Nevertheless, it is clear that over $5 \mathrm{~km}$ of subsidence has occurrcd since the onset of rifting at the start of the Tithonian (Figure 10a).

The earliest evidence for minor rifting in the vicinity of the west Iberian margin is during the Late Triassic (older than $208 \mathrm{Ma}$ [Wilson et al., 1989]; we use the timescale of Harland et al. [1990] in this paper). This preceded by more than 50 m.y. the two main periods of rifting during the Late Jurassic and the Early Cretaceous that accompanied continental breakup. Since the lithosphcre would have fully recovered thermally from the Late Triassic minor rifting by the time the syn-breakup rifting occurred, we model here only the rifting and subsidence associated with the continental breakup during the Late Jurassic and Early Cretaceous (152-114 Ma).

In the first, minor, rifting episode that started just before the end of the Jurassic, about $500 \mathrm{~m}$ of Tithonian (152-146 Ma) carbonates were deposited. The average water depth during deposition of these limestones was about $50 \mathrm{~m}$, and it never exceeded $100 \mathrm{~m}$ [Moullade et al., 1988; Mauffret and Montadert, 1988]. There is some indication of a slight deepening of the upper section of the limestones compared to the basal portions. The subsidence observations can be accounted for by a stretching factor of about 1.08 (Figure 10a). The subsequent main rifting phase started in the early Valanginian (141 Ma). Since the total crustal thinning is the cumulative result of both phases of rifting, the overall stretching factor of 4.3 can therefore be accounted for by a stretching factor of 1.08 in the first phase, followed by a factor of 4.0 in the second, main phase.

The sedimentary record suggests that the main rifting phase continued until continental breakup occurred in the late Aptian (114 Ma), and therefore spanned a period of about 25 m.y. Similar estimates of the duration of continental rifting have been inferred from other North Atlantic margins [Bown and White, 1995a], although it is difficult to tie down the duration with much precision. We therefore show subsidence curves in Figure 10a for durations of the main rifuing phase of $2,10,20$, and $30 \mathrm{~m} . y$. , using the stretching factor of 4.0 inferred jointly from the subsidence history and the seismically determined crustal thickness.

Given the uncertainties inherent in the paleodepth 


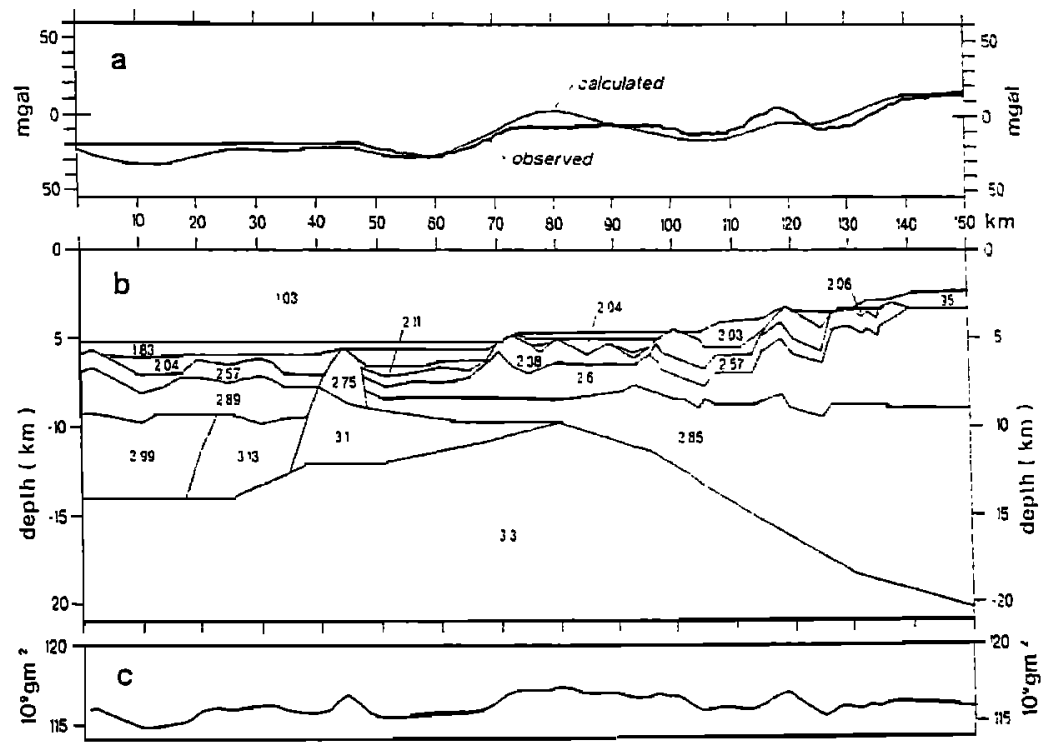

Figure 9. Gravity modeling based on the density model obtained from the final velocity model for line 6. (a) Free air anomaly calculated using densitics derived from seismic vclocities and slightly adjusted within the lower crust. The thick line is the observed gravity and the thin line the calculated gravity values. (b) Adjusted density model used to produce the calculaled gravity profile shown in Figure 9a. Densities are in megagrams per cubic meter. (c) Load anomaly across the adjustcd model.
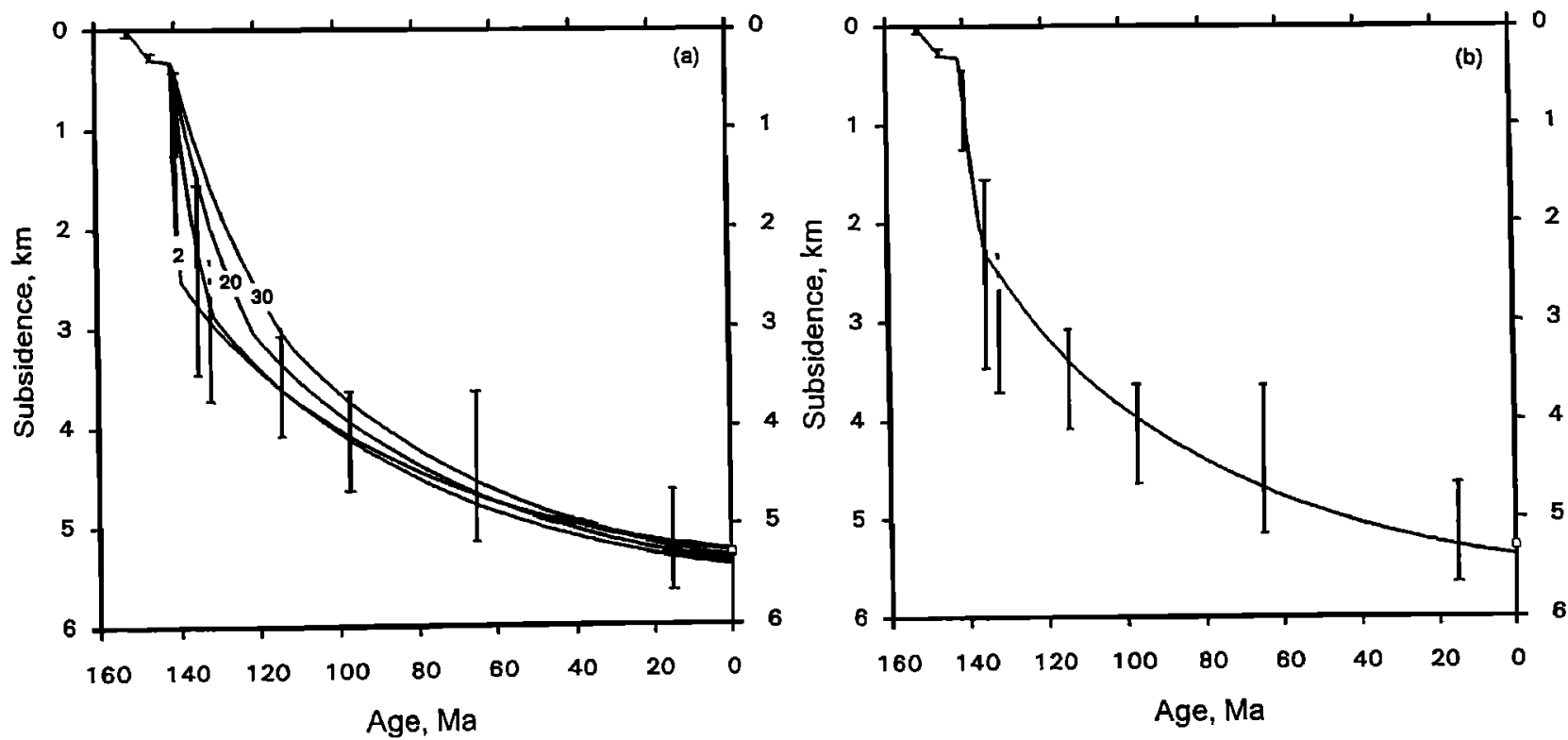

Figure 10. (a) Model subsidence curves calculated for finite duration rifting, superimposed on water-loaded basement subsidence measurements from postrift sediments recovered from ODP Sites 638, 639, and 641 [Boillot and Winterer, 1988] on the Galicia Bank continental margin (see Figure 8 for location of sites along profile GP101 and Figure 1 for location of line 6 which is coincident with profile GP101). Paleobathymetry estimates are from Mauffrel and Montadert [1988] and Moullade et al. [1988], with the upper and lower limits corresponding to the uncertainty in the palcobathymetry. Due to the uncertain nature of sea level changes, no corrections were applicd for custatic changes in sca level. Theoretical subsidence curves are calculated using the method of Bown and White [1995a] with the physical constants listed in their Table 1, a normal mantle potential temperature of $1300^{\circ} \mathrm{C}$, and a $125-\mathrm{km}$-hick lithosphere prior to stretching. The lithosphere is extended by a stretching factor of 1.08 betwecn 152 and $146 \mathrm{Ma}$ and by a stretching factor of 4.0 starting at $141 \mathrm{Ma}$. Curves are shown for durations of the second phase of rifting of 2,10,20, and 30 m.y. (b) A model that allows for a variable rate of rifting over the $27-\mathrm{m}$.y. period of the main rifting between about 141 and $114 \mathrm{Ma}$, with the greatest stretching factor (beta $=2.5$ ) between 141 and $135 \mathrm{Ma}$ and a smaller stretching factor of 1.6 between 135 and $114 \mathrm{Ma}$ in agrecment with geological observations of sedimentation and faulting patterns. 
estimates, we find a good match between the observed and the predicted subsidence history using the overall strctching factor of 4.3 inferred from the seismic refraction profile (Figure 10a). The data are consistent with a rifting duration of 0-15 m.y., which is somewhat shorter than the duration of rifting inferred from the sedimentary record. For stretching durations of more than 5 m.y. the Bown and While model predicts that less than $100 \mathrm{~m}$ of melt is generated by the decompression of dry mantle, so we do not expect significant addition of new igneous rock to the crust over this portion of the continental margin.

There is an abrupt increase in the water-loaded basement depth of 2-3 km over the first 10 m.y. (141-131 Ma) of the main rifting phase, followed by a more gradual subsidence to the present day (Figure 10). At the end of the Tithonian (146 Ma) the seafloor depth was less than $100 \mathrm{~m}$, but by the end of the Hauterivian $(132 \mathrm{Ma})$ and thereafter, it had increased to around the depth of the carbonate compensation depth (2200) $\mathrm{m})$, or greater. This suggests that the rate of stretching was greatest near the beginning of the main rifting phase and decreased through the remainder of the synrift sequence until the late Aptian (114 Ma). A similar conclusion is indicated by the movement on a fault bounding a tilled fault block ncar the ODP holes; the throw on this fault was as much as $2.5 \mathrm{~km}$ during the Valanginian to Hauterivian (141-132 Ma) but moved only a further $1.0 \mathrm{~km}$ during the remainder of the rifting from the Hauterivian to the end of the Aptian (132-112 Ma) [Mauffret and Montadert, 1988].

In Figure 10b we show the predicted subsidence curve from a model that allows for a variable rate of rifting during the main rifting phase (141-114 Ma) with the highest rate of stretching in the earlier period between 141 and $135 \mathrm{Ma}$. Although the backstripped basement depths are sufficiently uncertain to mean that this variable rate stretching model does not produce a significantly better fit than the uniform rate stretching model, it is in better agreement with the geological constraints mentioned above, and so we suggest that this represents the best subsidence curve for the upper margin. It is also in better agreement with the overall duration of the rifting event of about 25 m.y. inferred from the geology than is the uniform strain rate model for which results are shown in Figure 10a. No melting occurs in this finite-duration stretching model, so no new igneous rocks were added to this portion of the continental margin.

As has been found commonly elsewhere, the stretching factor of 4.3 that we deduce from the crustal thinning in the vicinity of the ODP sites is rather greater than the estimate of about 3 deduced from the geometry of the large tilted fault blocks on this margin [Louden et al., 1991]. The discrepancy may be explained by a component of simple shear in the upper, brittle crust and by faulting on minor faults that are not evident on the seismic reflection profiles.

\section{Melt Generation Beneath the Rifted Continental Crust at the Foot of the Continental Slope}

The most highly attenuated crust near the foot of the Galicia Bank continental slope occurs just east of the peridotite ridge. The thickness between the top of acoustic basement and the Moho deduced from profile 6, excluding postrift sediments, is $4.7 \mathrm{~km}$ (Figure 7). We interpret the lower part of this to be serpentinized mantle, with the water circulation required for serpentinization facilitated by the fractured, permeable nature (immediately after rifting) of the highly stretched continental crust. So our bcst estimate of the thickness of attenuated continental crust plus melt that may be intruded during the rifting process is about $3 \mathrm{~km}$, although if the lower part is not in fact serpentinized peridotite, then this could be as high as $4.7 \mathrm{~km}$.

In general, as the lithosphere is stretched and thinned, partial melt generated as the underlying mantle decompresses is added to the crust. The combination of crustal thinning by stretching with crustal thickening by the addition of melt is such that the overall final crustal thickness for any given rifting duration does not change significantly for stretching factors in excess of approximately 10 (Figure 11). However, for any given stretching factor, the predicted overall crustal thickness is less as the duration of the rifting increases (Figure 11). This is because less melt is generated over longer durations of rifting (Figure 12) as already explained. For normal temperature mantle, if the duration of rifting is sufficiently long, no melt at all is generated by mantle decompression; this happens, for example, for rifting over periods in excess of 12 m.y: for a stretching factor of 5 , in excess of $28 \mathrm{~m}$.y. for a stretching factor of 10 , and in excess of $40 \mathrm{~m}$.y. for a stretching factor of 20 .

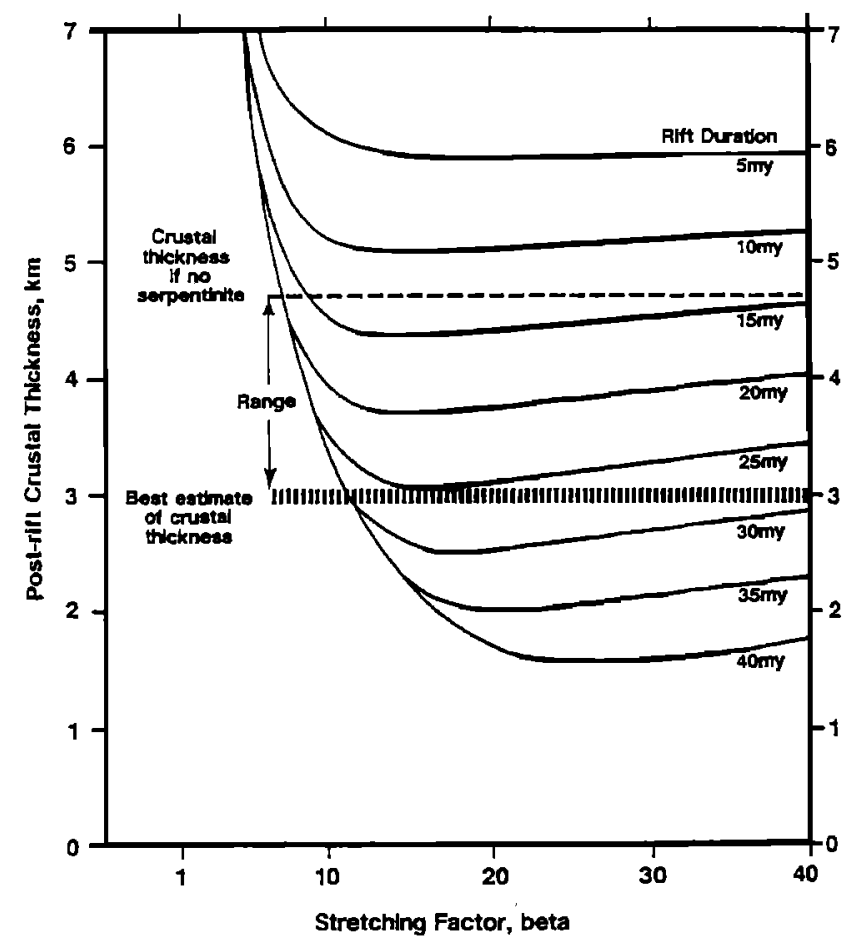

Figure 11. Variation of final crustal thickness with stretching factor for continental lithosphere underlain by normal mantle with a potential temperature of $1300^{\circ} \mathrm{C}$ for a range of finiteduration rifting periods up to $40 \mathrm{~m}$.y. Final crustal thickness is the sum of the continental crust thinned by stretching plus the melt generated as a result of mantle decompression. The vertically hatched area shows that the best estimate of $3 \mathrm{~km}$ for the crustal thickness (excluding post-rift sediments) at line $7 \mathrm{E}$ near the foot of the continental slope requires stretching factors greater than 11 and a rift duration of at least 25 m.y. The dashed line shows the limit assuming that none of the crust is serpentinized (requires a finite duration of more than 13 m.y.). Melt generation during finite-duration rifting uses the method described by Bown and White [1995a], with the physical constants shown in their Table 1 . 

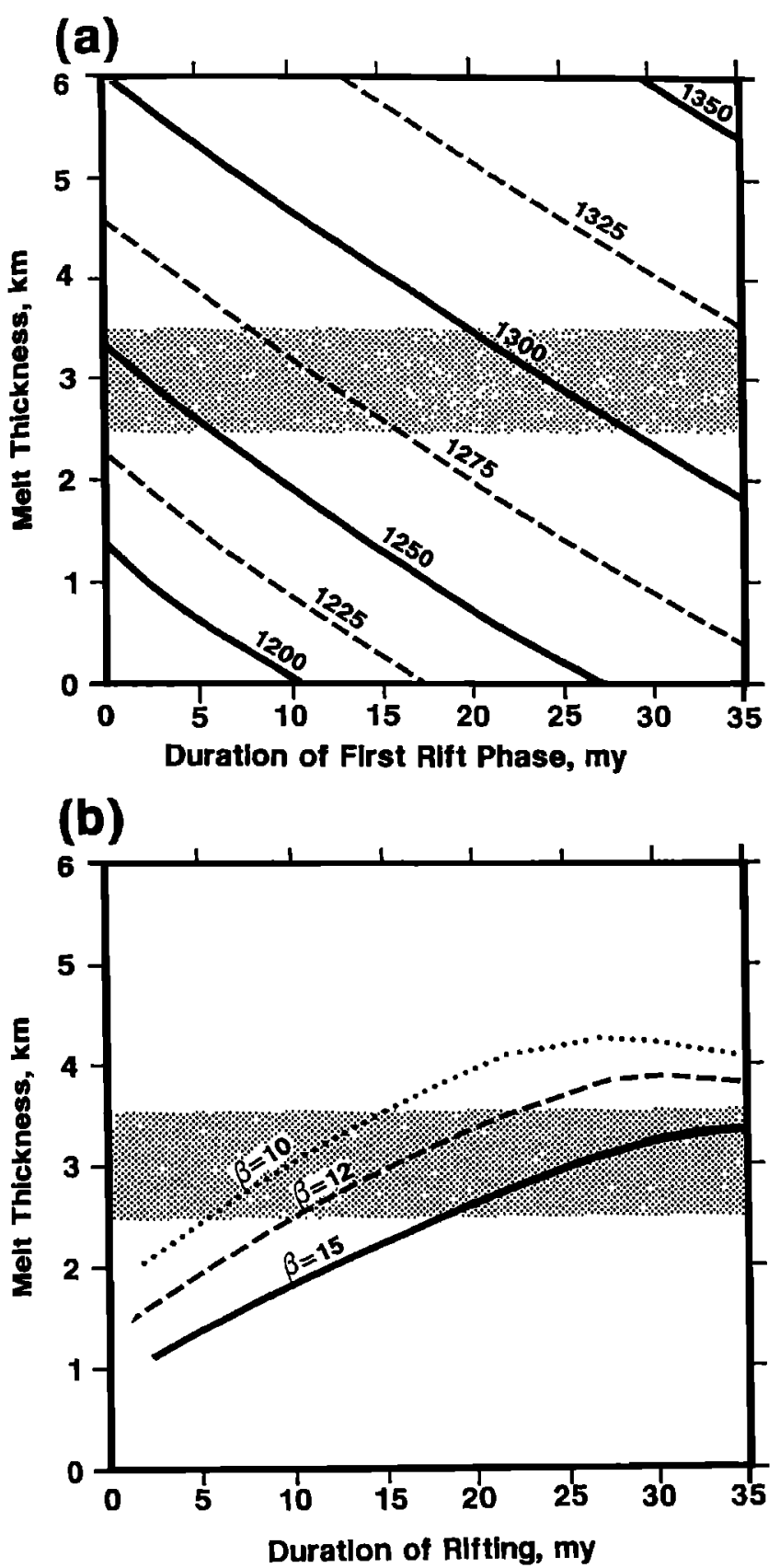

Figure 12. (a) Variation of melt thickness with rift duration for a stretching factor of 50, appropriate for the generation of oceanic crust at a spreading center. Curves are shown for mantle potential temperatures of $1200^{\circ}-1400^{\circ} \mathrm{C}$ in $25^{\circ} \mathrm{C}$ intervals. (b) Variation of melt thickness produced during a rapid rifting phase lasting $2 \mathrm{~m}$.y. following an earlier rifting phase of variable duration. All the melt produced during the earlier rifting phase is assumed to be accumulated elsewhere in continental crust. Curves are shown for stretching factors during the initial long-duration rifting of 10,12 , and 15 , such that the overall stretching factor is 50 in each case. This calculation mimics the generation of the oldest oceanic crust from mantle which has been previously allowed to cool by conductive heat loss beneath a slowly extending continental margin. The observed crustal thickness of the oldest oceanic crust adjacent to the Galicia Bank continental margin is 2.5$3.5 \mathrm{~km}$ (shaded area), which requires an initial rift duration of $-25 \mathrm{~m} . \mathrm{y}$.
The observed final crustal thickness, excluding post-rift sediments, of about $3 \mathrm{~km}$ immediately east of the peridotite ridge requires stretching factors greater than 11 and a rift duration of more than $25 \mathrm{~m} . \mathrm{y}$. (vertically hatched region in Figure 11). Smaller stretching factors than this are incapable of producing sufficiently thin crust, while shorter durations of rifting produce too much melt and thus, again, cannot result in crust as thin as that observed. If we make the extreme assumption that none of the section above the Moho represents serpentinized peridotite, then the total crustal thickness of $4.7 \mathrm{~km}$ would require stretching factors of more than 7 and a rift duration greater than 13 m.y. (dashed line, Figure 11).

We conclude that the thin crust found immediately to the east of the peridotite ridge requires rifting over a period of at least 13 m.y., and probably of the order of 25-30 m.y. This is consistent with the results of the subsidence analysis from the more landward portion of the continental margin discussed above.

\section{Melt Generation Beneath the Oceanic Spreading Center Under Initial and Steady State Conditions}

We interpret the crust west of the peridotite ridge to be fully oceanic crust (i.e. it contains no residual continental crust). The first $15-$ to $20-\mathrm{km}$ width of oceanic crust created immediately following continental breakup has a thickness of only $2.5-3.5 \mathrm{~km}$, with an underlying high-velocity region that we interpret as serpentinized peridotite mantle (Figure 7). Thereafter it attained a normal crustal thickness of about 7 $\mathrm{km}$, indicating that the underlying mantle had a normal temperature. Four heat flow stations over the oldest oceanic crust west of Galicia Bank yield a mean heat flow of $44 \mathrm{~mW}$ $\mathrm{m}^{2}$ [Louden et al., 1991], again consistent with the underlying mantle having a normal temperature.

We suggest that the observation that the mean sedimentunloaded basement depth of the oceanic crust west of the Galicia Bank margin is about $0.4-0.5 \mathrm{~km}$ deeper than that expected of normal oceanic crust [Louden et al., 1991; Sclater and Francheteau, 1970] is simply a function of the isostatic response of a lithosphere with an unusually thin oceanic crust. As normal oceanic crustal thicknesses of about $7 \mathrm{~km}$ were generated farther west, the basement depth became shallower and is now consistent with normal oceanic depth-age curves.

The transient, abnormally thin, oceanic crust produced immediately following continental breakup may be explained by two interlinked factors. First, the long duration of stretching of the continental lithosphere prior to breakup, already mentioned, would have allowed the slowly upwelling mantle to cool by conductive heat loss both vertically and laterally, thus decreasing the volume of melt produced when it finally welled up, perhaps more rapidly, beneath the new oceanic spreading center. Second, the extraction of some melt from the upwelling mantle beneath the continental rift may have partially depleted the mantle, thus again reducing the volume of melt that was produced when this mantle subsequently completed its decompression beneath the new oceanic spreading center. Both effects are only transient, since the mantle lying beneath the continental rift and affected by the long, prebreakup rifting would rapidly complete its decompression and become replaced by fresh, fertile mantle beneath the developing oceanic basin. 
The conductive cooling of underlying mantle due to the prolonged continental stretching has a particularly prominent effect on the oceanic crust formed adjacent to the Galicia Bank margin because the seafloor spreading rate is in any case very low here. Full seafloor spreading rates of about $20 \mathrm{~mm} \mathrm{yr}^{-1}$ have been reported from modeling seafloor spreading magnetic anomalies in the Iberia Abyssal Plain adjacent to the continental margin by Whitmarsh et al. [1990] and in the Tagus Abyssal Plain by Pinheiro et al. [1992]; Bown and White [1994] calculated a lower full rate of $13 \mathrm{~mm} \mathrm{yr}^{-1}$ based on the estimated time of breakup and the age of anomaly 34 , the oldest preserved seafloor spreading magnetic anomaly adjacent to Galicia Bank; while Srivastava and Roest [1995] reported an even lower full rate of only $10 \mathrm{~mm} \mathrm{yr}^{-1}$ bascd on plate reconstructions. Whichever is correct, the range of 10-20 $\mathrm{mm} \mathrm{yr}^{-1}$ full spreading rate is in the borderline region where conductive cooling has an impact in reducing melt gencration even at a steady state spreading axis [Bown and White, 1994]. So the additional mantle cooling beneath the nascent continental margin may have becn sufficient to decrease the melt thickness markedly until the ncw ocean had opencd sufficiently for the spreading center to cscape the influcnce of the cooler asthenospheric material.

To demonstrate the effect of mantle cooling on melt generation, we show in Figure 12a the predictions of melt thickness from a finite-duration strelching model. Wc assume a total stretching factor of 50, which is appropriate for melt generation at an oceanic spreading center. The curve at a normal potential temperaturc of $1300^{\circ} \mathrm{C}$ shows how less melt is produced as the duration of the rifting increases; for example, $6 \mathrm{~km}$ of igneous crust is produccd by instantancous rifting, whereas the observed oceanic crustal thickness of 2.5-3.5 $\mathrm{km}$ is produced for $1300^{\circ} \mathrm{C}$ mantle if the rifting duration is 20-30 m.y. (Figure 12a). If the mantle potential temperature is below normal, even less melt is produced. For examplc, if the mantle tempcrature was $100^{\circ} \mathrm{C}$ bclow normal, at $1200^{\circ} \mathrm{C}$, even instantancous melting would producc only $1.3 \mathrm{~km}$ of melt. Since even the thinnest oceanic crust we observe is $2.5-3.5 \mathrm{~km}$ thick, the temperanure would not have been this low. Even a mantle temperature only $50^{\circ} \mathrm{C}$ bclow normal, at $1250^{\circ} \mathrm{C}$, can produce only $3.3 \mathrm{~km}$ of mclt when rifting is instantaneous.

Although there is a trade-off between mantle tcmperature and rift duration (Figure 12a), we have chosen to assume that the mantle temperature was normal at $1300^{\circ} \mathrm{C}$, and that the reduced melt thickness immediately west of the peridotite ridge was due to transient mantle cooling as a result of longduration stretching. Our justification for this is that heat flow measurements are normal over this region of old continental crust (44 $\mathrm{mW} \mathrm{m}^{-2}$ [Louden et al., 1991]) and that the generation of thin oceanic crust and dceper than normal basement was only transient, reverting to normal thickness crust as seafloor spreading proceeded.

The model we propose for the formation of thin oceanic crust is one in which the stretching of the continental lithosphere prior to breakup was slow and of long duration (see preceding sections), followed by relatively rapid stretching as the new oceanic crust was generated. The 15- to $20-\mathrm{km}$-wide anomalous oceanic crust was formed in about 2 m.y., so in our calculations we allow the main phase of rifting to occur over a variable period of up to $35 \mathrm{~m}$.y., with a postbreakup rifting phase lasting a fixed period of 2 m.y. We assume that any melt generated during the initial slow continental extension was removed from the mantle and emplaced in the continental crust. The melt generated during the subsequent more rapid extension which generated the oceanic crust is shown by the curves in Figure $12 \mathrm{~b}$. This provides a way for us to model the mantle cooling resulting from the slow extension prior to the postbreakup onset of seafloor spreading. We show predictions of the melt generated in the postbreakup phase of stretching, which generated the oceanic crust, for initial stretching factors of 10,12 , and 15 (Figure 12b), which span the probable range of lithospheric stretching factors deduced from the continental crust immediately landward of the peridotite ridge (see preceding section).

For an initial stretching factor of 12 applied over a period of 10-25 m.y., which is appropriate for the stretched continental crust on the landward side of the pcridotite ridge (Figure 11), an occanic crustal thickncss of $2.5-3.5 \mathrm{~km}$ is formed (Figurc 12b). Although this model is only an approximation to the real thermal history of the margin, it does show consistently that a stretching duration of 10-25 m.y., during the main prebrcakup phase of development of the continental rift, can explain the observed subsidence and the lack of melt under the upper continental margin, the thickness of the highly stretched continental crust adjacent to the peridotite ridge, and the reduced thickness of the oldest oceanic crust formed adjaccnt to the pcridotitc ridge. Once a fully devcloped occanic basin had opened, cool mantle caused by the transient thermal conditions associated with the slow continental stretching was replaced by normal tempcrature asthenosphcric mantle, and normal thickness oceanic crust was generated at the spreading center.

\section{Conclusions}

Our study of the decp structure of the Galicia Bank rifted continental margin off wcstem Ibcria provides seismic velocity and gravity models along a transect of the margin from continental to occanic crust. These have been integrated with numerical models of melting to explain the seismic observations as follows.

1. The continental crust thins systematically westward from 17 to $2 \mathrm{~km}$; the crust-mantle boundary rises from a depth of about $20 \mathrm{~km}$ below sea level bencath the west flank of Galicia Bank to about $9 \mathrm{~km}$ immcdiately east of a marginparallel peridotite ridge. Immediatcly west of the peridotite ridge the oceanic crust is only $2.5-3.5 \mathrm{~km}$ thick, but $20 \mathrm{~km}$ farther west it reaches a normal thickness of $7 \mathrm{~km}$.

2. The peridotite ridge represents the top of a $-60-\mathrm{km}$ wide, lens-shaped body of serpentinized peridotite that extends beneath both thinned continental and thin oceanic crust. The main body has seismic velocities of $7.2-7.6 \mathrm{~km} \mathrm{~s}^{-1}$.

3 . The $S$ reflector extends, more or less continuously, over $50 \mathrm{~km}$ of the continental margin on multichannel seismic reflection profiles. When superimposed on a reflection time version of the velocity model the $S$ reflector is clearly intracrustal at its east end. Westward, $S$ gradually cuts down to lower crustal levels, and the westernmost $20 \mathrm{~km}$ coincides within $0.5 \mathrm{~s}$ with the top of the serpentinized peridotite lens (i.e., the original crust-mantle boundary). The fact that $S$ is a midcrustal reflector in its eastem part renders almost impossible the hypothesis that the seafloor exposure of the peridotite ridge occurred by a process of tectonic denudation, with $S$ acting as a detachment fault.

4. The asthenospheric potential temperature at the time of rifting was normal, i.e., about $1300^{\circ} \mathrm{C}$, consistent with heat 
flow measurements and with our observation of a normal oceanic crustal thickness at the extreme west end of the transect. We use numerical models of mclt generation that include the creation of melt as a function of both the stretching factor and the duration of stretching. The models assume that lithosphere is thinned by pure shear. We also use borehole subsidence information to constrain our eventual model of the rifting. Towards the east (landward) end of the transect the continental crust experienced a total strctching factor of 4.3 , which most likely occurred in two stages (1.08 in the Late Jurassic-earliest Cretaceous followed by 4.0 in the Early Cretaceous). The main synrift faulting, sedimentation, and subsidence history at this eastem end of the transect is matched best by rifting over a $27 \mathrm{~m}$.y. period from 141 to 114 Ma. No melt was generated during this rift phase.

The most highly attenuated continental crust (3.0 or $4.7 \mathrm{~km}$ thick, depending on whether the $7.2-7.6 \mathrm{~km} \mathrm{~s}^{-1}$ layer is attributed to serpentinized peridotite or to crust, respectively), which may include melt products, occurs just east of the peridotite ridge. A 3.0 (4.7) $\mathrm{km}$ crust requires stretching factors of more than 11 (7) and a rift duration of more than 25 (13) m.y. The 2.5- to $3.5-\mathrm{km}$-thick oceanic crust in a $15-$ to $20-\mathrm{km}$-wide zone immediately west of the peridotite ridge is explained by transient thermal effects due to conductively cooled mantle that temporarily reduced the amount of mantle melting immediately following continental breakup. After about $2 \mathrm{~m}$.y., steady state seafloor spreading was established, giving rise to the normal 7-km-thick oceanic crust that is observed farther west.

Acknowledgments. S.J.H. thanks Shell International Petroleum Co. Ltd. for a Studentship. This work was supported by the Institut Français de Recherche pour l'Exploitation de la Mer (IFREMER) and the Natural Environment Research Council (NERC). We thank John Hopper, Dale Sawyer, and an anonymous referee for their reviews and the Master and crew of $\mathrm{R} / \mathrm{V}$ Le Surout for their assistance in collecting, often under difficult conditions, the seismic data on which this work is based. Department of Earth Sciences, University of Cambridge contribution 4710 .

\section{References}

Ahern, J.L., and D.L. Turcotte, Magma migration beneath an ocean ridge, Earth Planet. Sci. Lett., 45, 115-122, 1979.

Banda, E., M. Tomé, and Iberia Atlantic Margins Group, Iberian Atlantic Margins Group investigates deep structure of ocean margins, Eos, Transactions, AGU, 76, 25, 28-29, 1995.

Barton, P.J., The relationship between seismic velocity and density in the continental crust - a useful constraint?, Geophys. J. R. Astron. Soc., 87, 195-208, 1986.

Bassi, G., Relative importance of strain rate and rheology for the mode of continental extension, Geophys. J. Int., 122, 195-210, 1995.

Beslier, M.-O., M. Ask, and G. Boillot, Ocean-continent boundary in the Iberia Abyssal Plain from multichannel seismic data, Tectonophysics, 218, 383-393, 1993.

Boiliot, G., and E.L. Winterer, Drilling on the Galicia margin: Retrospect and prospect, Proc. Ocean Drill. Program, Sci. Results, 103, 809-823, 1988.

Boillot, G. et al., Tectonic denudation of the upper mantle along passive margins: a model based on drilling results (ODP Leg 103. westem Galicia margin, Spain. Tectonophysics, 132, 335-342, $1987 \mathrm{a}$.

Boillot, G., et al., Leg 103, Proc. Ocean Drill. Program, Initial Reports, 103, Pp. 663, $1987 \mathrm{~b}$.

Boillot, G., J. Girardeau, and J. Komprobst, Rifting of the Galicia margin: Crustal thinning and emplacement of mantle rocks on the seafloor, Proc. Ocean Drill. Program Sci. Results, 103, 741-756, $1988 \mathrm{a}$.

Boillot, G., M.C. Comas, J. Girardeau, J. Kornprobst, J.-P. Loreau, J.
Malod, D. Mougenot, and M. Moullade, Preliminary results of the Galinaute cruise: Dives of the submersible Nautile on the westem Galicia margin, Spain, Proc. Ocean Drill. Program, Sci. Results, $103,37-51,1988 \mathrm{~b}$.

Boillot, G. et al., Leg 103, Proc. Ocean Drill. Program, Sci. Results, 103,858 pp., $1988 \mathrm{c}$.

Boillot, G., G. Féraud, M. Recq, and J. Girardeau, Undercrusting by serpentinite beneath rifted margins, Nature, 34l, 523-525, 1989.

Boillot, G., M.-O. Beslier, and J. Girardeau, Nature, structure and evolution of the ocean-continent boundary: The lesson of the west Galicia margin (Spain), in Rifted Ocean-Continent Boundaries, NATO ASI Ser. C, vol. 463, edited by E. Banda, M. Torné, and M. Talwani, pp. 219-230, Kluwer, Norwell, Mass., 1995.

Boutilier, R.R., and C.E. Keen, Geodynamic models of faultcontrolled extension, Tectonics, 13, 439-454, 1994.

Bown, J.W., and R.S. White, Variation with spreading rate of oceanic crustal thickness and geochemistry, Earth Planet. Sci. Lett., 121, 435-449, 1994.

Bown, J.W., and R.S. White, The effect of finite extension rate on melt generation at continental rifts, J. Geophys. Res., 100, 18,011$18,029,1995 \mathrm{a}$.

Bown, J.W., and R.S. White, Finite duration rifing, melting and subsidence at continental margins, in Rifted Ocean-Continent Boundaries, NATO ASI Ser.C, vol. 463, edited by E. Banda, $M$. Tomé, and M. Talwani, pp. 31-54, Kluwer, Norwell, Mass., $1995 b$.

Carlson, R.L. and C.N. Henrick, Densities and porosities in the oceanic crust and their variations with depth and age, J. Geophys. Res., 95, 9153-9170, 1990.

Chapman, C.H. and R. Drummond, Body-wave seismograms in inhomogeneous media using Maslov assymptotic theory, Bull. Seismol. Soc. Am., 72, suppl., s277-s317, 1982.

Cordoba, D., E. Banda, and J. Ansorge, The Ilercynian crust in northwestern Spain: A seismic survey, Tectonophysics, 132, 1987.

de Charpal, O., P. Guennoc, L. Montadert, and D.G. Roberts, Rifting, crustal attenuation and subsidence in the Bay of Biscay, Nature, 275, 706-711, 1978.

Eldholm, O., and K. Grue, North Atlantic volcanic margins: Dimensions and production rates, J. Geophys. Res., 99, 29552968, 1994.

Goldberg, D., and B. Zinszner, Acoustic properties of altered peridotite at Site 637 from laboratory and sonic waveform dara. Proc. Ocean Drill. Program, Sci. Results, J03, 269-276, 1988.

Groupe Galice, The continental margin of Galicia and Portugal, acoustic stratigraphy, dredge stratigraphy and structural evolution, Initial Rep. Deep Sea Drill. Proj., 47, 633-662, 1979.

Harland, W. B., R.L. Armstrong, A.V. Cox, L. Craig, A.G. Smith, and D.G. Smith, A Geological Timescale 1989, Cambridge Univ. Press, New York, 1990.

Hoffman, H.-J., and T.J. Reston, Nature of the $S$ reflector beneath the Galicia Banks rifted margin: Preliminary results from pre-stack depth migration, Geology, 20, 1091-1094, 1992.

Hopper, J.R., and W.R. Buck, The initiation of rifting at constant tectonic force: Role of diffusion creep, J. Geophys. Res., 98, 16,213-16,221, 1993.

Horsefield, S.J., R.B. Whitmarsh, R.S. White, and J.-C. Sibuet, Crustal structure of the Goban Spur rifted continental margin. Geophys. J. Int., 119, 1-19, 1994.

Keen, C.E., R.C. Courtney, S.A. Dehler, and M.-C. Williamson. Decompression melting at rifted margins: Comparison of model predictions with the distribution of igneous rocks on the eastern Canadian margin, Earth Planet. Sci. Lett., I2I, 403-416, 1994.

Kirk, R.E., J.J. Langford, and R.B. Whitmarsh, A three-component ocean-bottom seismograph for controlled source seismology, Mar. Geophys. Res., 5, 327-341, 1982.

Krawczyk, C.M., and T.J. Reston, Detachment faulting and continental break-up: The $S$ reflector offshore Galicia, in Rifted Ocean-Continent Boundaries, NATO ASI Ser. C, Vol.463, edited by E. Banda, M. Tomé, and M. Talwani, pp. 231-246, Kluwer, Amsterdam, 1995.

Lalaut, P., J-C. Sibuet, and C.A. Williams. Presentation d'une carte gravimetrique de l'Atlantique Nord-Est, C. R. Acad. Sci. Ser. II a, 292, 597-599, 1981.

Latin, D., and N. White, Generating melt during lithospheric extension: Pure shear vs simple shear, Geology, 18, 327-331, 1990. 
Lister, G.S., M.A. Etheridge, and P.A. Symonds, Detachment models for the formation of passive continental margins, Tectonics, 10 , 1038-1064, 1991.

Louden, K. E., J-C. Sibuet, and J-P. Foucher, Variations in heat flow across the Goban Spur and Galicia Bank continental margins, $J$. Geophys. Res., 96, 16,131-16,150, 1991.

Mamet, B., M.C. Comas, and G. Boillot, Late Paleozoic basin on the west Galicia Atlantic margin, Geology, 19, 738-741, 1991.

Martins, L.S., Actividade ígnea Mesozoica em Portugal: Contribuição Petrológica e Geoquímica. (Mesozoic Igneous Activity in Portugal: Contribution from Petrological and Geochemical studies, in Portuguese), PhD Thesis, 270 pp., Univ. Lishoa, Lisbon, Portugal, 1991.

Mauffret, A. and L. Montadert, Rift tectonics on the passive continental margin off Galicia (Spain), Mar. Pet. Geol., 4, 49-70, 1987.

Mauffret, A. and L. Montadert, Seismic stratigraphy off Galicia (Spain), Proc. Ocean Drill. Program Sci. Results, 103, 13-30, 1988.

McKenzie, D., The generation and compaction of partially molten rock, J. Petrol., 25, 713-765, 1984.

McKenzie, D., and M.J. Bickle, The volume and composition of melt generated by extension of the lithosphere, J. Petrol., 29, 625-679, 1988.

Moullade, M., M.-F. Brunet, and G. Boillot, Subsidence and deepening of the Galicia margin: The palcoenvironmental control, Proc. Ocean Drill. Program Sci. Results, 103, 733-740, 1988.

ODP Leg 103 Shipboard Scientific Party, Introduction, objectives and principal results: Ocean Drilling Program Leg 103, West Galicia margin, Proc. Ocean Drill. Program Initial Rep., 103, 3-17, 1987.

Parson, L.M., D.G. Masson, C.G. Pelton, and A.C. Grant. Seismic stratigraphy and structure of the east Canadian continental margin between $41^{\circ}$ and $52^{\circ}$ N. Cañ. J. Earth Sci., 22, 686-703, 1985.

Peddy, C., B. Pinet, D.G. Masson, R. Scrulton, J.-C. Sibuet, M.R. Warner, J.P. Lefort, and I.J. Schroeder, Crustal structure of the Goban Spur continental margin, northeast Atlantic, from deep seismic reflection profiling, J. Geol. Soc., 146, 427-437, 1989.

Pedersen, $T$, and H.E. Ro, Finite duration extension and decompression melting, Earth Planet. Sci. Lett., 113, 15-22, 1992.

Peirce, C. and P.J. Barton, Crustal structure of the Madeira-Tore Rise, eastem North Atlantic - Results of a DOBS wide-angle and nomal incidence seismic experiment in the Josephine seamount region, Geophys. J. Int., 106, 357-378, 1991.

Pinheiro, L.M., R.B. Whitmarsh, and P.R. Miles, The ocean-continent boundary off the westem continental margin of Iberia, II, Crustal structure in the Tagus Abyssal Plain, Geophys. J. Int., 109, 106$124,1992$.

Reid, I., Crustal structure of a nonvolcanic rifted margin east of Newfoundland, J. Geophys. Res., 99, 15,161-15,180, 1994.

Reston, T.J., The $S$ reflector west of Galicia: The seismic signature of a detachment fault, Geophys. J. Int., in press, 1996.

Reston, T.J., C.M. Krawczyk, and H.J. Hoffmann, Detachment tectonics during Atlantic rifting: Analysis and interpretation of the $S$ reflection, the west Galicia margin, in The Tectonics, Sedimentation and Palaeoceanography of the North Atlantic Region, edited by R. A. Scrutton, M. S. Stoker, G.B. Shimmield, and A.W. Tudhope, Geol. Soc. Spec. Publ., 90, 93-109, 1995.

Reston, T.J., C.M. Krawczyk, and D. Klaeschen, The $S$ reflector west of Galicia (Spain). Evidence for detachment faulting during continental breakup from prestack depth migration, J. Geophys. Res., 101, 8075-8091, 1996.

Ruppel, C., Extensional processes in continental lithosphere, J. Geophys. Res., 100, 24,187-24,215, 1995.

Sawyer, D.S., and D.L. Harry, Dynamic modelling of divergent margin formation: Application to the U.S. Atlantic margin, Mar. Geol., 102, 29-42, 1991.

Sclater, J.G., and J. Francheteau, The implications of terrestrial heat flow observations on current tectonic and geochemical models of the crust and upper mantle of the earth, Geophys. J. R. Astron. Soc., 20, 509-542, 1970.

Sibuet, J.-C., New constraints on the formation of the non-volcanic continental Galicia-Flemish Cap conjugate margins, J. Geol. Soc., 149, 829-840, 1992.

Sibuet, J.-C., J.-P. Maze, P. Amortila, and X. Le Pichon, Physiography and structure of the westem Iberian continental margin off Galicia from Seabcam and seismic data, in Proc. Ocean Drill. Program Initial Rep., 103, 77-97, 1987.
Sibuet, J.-C., V. Louvel, R.B. Whitmarsh, R.S. White, S.J. Horsefield, B. Sichler, P. Leon, and M. Recq, Constraints on rifting processes from refraction and deep-tow magnetic data: The example of the Galicia continental margin (West Iberia), in Rifted OceanContinent Boundaries, NATO ASI Ser. C. vol.463, edited by Banda E., M. Torné, and M. Talwani, pp. 197-218, Kluwer, Amsterdam, 1995.

Srivastava, S.P. and W. Roest, Nature of thin crust across the southwest Greenland margin and its bearing on the localion of the continent-ocean boundary, in Rifted Ocean-Continent Boundaries, NATO ASI Ser. C, vol. 463, edited by E. Banda, M. Torné, and M. Talwani, pp. 95-120, Kluwer, Amsterdam, 1995.

Thommeret, M., G. Boillot, and J.-C. Sibuet, Structural map of the Galicia margin, Proc. Ocean Drill. Program, Sci. Results, 103, 31 36, 1988.

Todd, B.J. and I. Reid. The continent-ocean boundary south of Flemish Cap: Constraints from seismic refraction and gravity, Can. J. Earth Sci., 26, 1392-1407, 1989.

Tucholke, B.E., J.A. Austin, and E. Uchupi, Crustal structure and riftdrift evolution of the Newfoundland Basin, in Extensional Tectonics and Stratigraphy of the North Allantic Margins, edited by A.J. Tankard and H.R. Balkwill, AAPG Mem., 46, 247-263, 1989.

Watson, S., and D. McKenzie, Melt generation by plumes: A study of Hawaiian volcanism, J. Petrol., 32, 501-537, 1991.

White, R., and D. McKenzie, Magmatism at rift zones: The generation of volcanic continental margins and flood basalts, J. Geophys. Res., 94, 7685-7729, 1989.

White, R.S., Magmatism during and after continental breakup, in Magmatism and the Causes of Continental Breakup, edited by B.C. Storey, T. Alabaster and R.J. Pankhurst, Geol. Soc. Spec. Publ. London, 68, 1-16, 1992a.

White, R.S., Crustal structure and magmatism of North Atlantic continental margins, J. Geol. Soc. London, 149, 841-854, $1992 \mathrm{~b}$.

White, R.S., D. McKenzie and K. O'Nions, Oceanic crustal thickness from seismic measurements and rare earth element inversions, $J$. Geophys. Res., 97, 19,683-19,715, 1992.

Whitmarsh, R.B., and P.R. Miles, Models of the development of the west Iberia rifted continental margin at $40^{\circ} 30^{\prime} \mathrm{N}$ deduced from surface and deep-tow magnetic anomalies, Journal of Geophy. Res., 100, 3789-3806, 1995.

Whitmarsh, R.B., F. Avedik, and M.R. Saunders, The seismic structure of thinned continental crust in the northern Bay of Biscay, Geophys. J. R. Astron. Soc., 86, 589-602, 1986.

Whitmarsh, R.B., P.R. Miles and A. Mauffret, The ocean-continent boundary off the western continental margin of Iberia, I, Crustal structure at 40³0'N, Geophys. J. Int., 103, 509-531, 1990.

Whitmarsh, R.B., L.M. Pinheiro, P.R. Miles, M. Recq, and J.-C. Sibuet, Thin crust at the westem Iberia ocean-continent transition and ophiolites, Tectonics, 12, 1230-1239, 1993.

Wilson, R.C.L., R.N. Hiscott, M.G. Willis, and F.M. Gradstein, The Lusitanian Basin of west-central Portugal: Mesozoic and Tertiary tectonic, stratigraphic and subsidence history, in Extensional Tectonics and Stratigraphy of the Norh Atlantic Margins, edited by H. R. Balkwill and A. J. Tankard, pp. 341-361, Am. Assoc. Petr. Geol., Tulsa, Okla, 1989.

Winterer, E.L., J. Gee, and J. van Waasbergen, The source area for lower Cretaceous clastic sediments of the Galicia margin: Geology and tectonic and erosional history, Proc. Ocean Drill. Program, Sci. Results, 103, 697-732, 1988.

S.J. Horsefield, Esso Expro UK Ltd., Mailpoint 25, Esso House, Ermyn Way, Leatherhead, Surrey KT22 8UY, England.

V. Louvel and J.-C. Sibuet, IFREMER Centre de Brest, B.P. 70, 29280 Plouzané, France.

M. Recq, UFR Sciences et Techniques, Université de Bretagne Occidentale, 6 avenue Gorgeu, B.P. 452, 29275 Brest Cedex, France.

R.S. White, Bullard Laboratories, Department of Earth Sciences, University of Cambridge, Madingley Road, Cambridge CB3 OEZ, England.

R.B. Whitmarsh, Challenger Division for Seafloor Processes, Southampton Oceanography Centre, European Way, Southampton SO14 3ZH, England. (e-mail: bob.whitmarsh@soc.soton.ac.uk)

(Received November 27, 1995; revised August 5, 1996; accepted August 21, 1996.) 